\title{
Petroleum Geology and Resources of the Amu-Darya Basin, Turkmenistan, Uzbekistan, Afghanistan, and Iran
}

By Gregory F. Ulmishek

U.S. Geological Survey Bulletin 2201-H 


\section{U.S. Department of the Interior \\ Gale A. Norton, Secretary \\ U.S. Geological Survey \\ Charles G. Groat, Director}

U.S. Geological Survey, Reston, Virginia: 2004

For more information about the USGS and its products:

Telephone: 1-888-ASK-USGS

World Wide Web: http://www.usgs.gov/

This publication is only available online at: http://pubs.usgs.gov/bul/b2201-h/

Any use of trade, product, or firm names in this publication is for descriptive purposes only and does not imply endorsement by the U.S. Government.

Although this report is in the public domain, permission must be secured from the individual copyright owners to reproduce any copyrighted materials contained within this report. 


\section{Foreword}

This report was prepared as part of the World Energy Project of the U.S. Geological Survey. In the project, the world was divided into 8 regions and 937 geologic provinces. The provinces have been ranked according to the discovered oil and gas volumes within each (U.S. Geological Survey World Energy Assessment Team, 2000). Of the 937 geologic provinces, 76 "priority" provinces (exclusive of the United States and chosen for their high ranking) and 52 "boutique" provinces (exclusive of the United States and chosen for their anticipated petroleum richness or special regional economic importance) were selected for appraisal of oil and gas resources. The petroleum geology of these priority and boutique provinces is described in this series of U.S. Geological Survey Bulletins. The statistical treatment of assessment data and detailed results of the assessment have been published earlier (U.S. Geological Survey World Energy Assessment Team, 2000), and only a summary of the assessment results is included in this report (see table 1).

The purpose of this effort is to aid in assessing the quantities of oil, gas, and natural gas liquids that have the potential to be added to global reserves within the next 30 years. These hydrocarbon volumes either reside in undiscovered fields whose sizes exceed the stated minimum-fieldsize cutoff value for the assessment unit (variable, but must be at least 1 million barrels of oil equivalent) or represent reserve growth of fields already discovered.

The total petroleum system constitutes the basic geologic unit of the oil and gas assessment. The total petroleum system includes all genetically related petroleum found in shows and accumulations (discovered and undiscovered) that has been generated by a pod or by closely related pods of mature source rock. This petroleum exists within a limited mappable geologic space, together with the essential mappable geologic elements (source, reservoir, and seal) that control the fundamental processes of generation, expulsion, migration, entrapment, and preservation of petroleum.

An assessment unit is a mappable part of a total petroleum system in which discovered and undiscovered fields constitute a single relatively homogeneous population such that the chosen methodology of resource assessment based on estimation of the number and sizes of undiscovered fields is applicable. A total petroleum system might equate to a single assessment unit. If necessary, a total petroleum system may be subdivided into two or more assessment units such that each assessment unit is sufficiently homogeneous in terms of geology, exploration considerations, and risk to assess individually.

A numeric code identifies each region, province, total petroleum system, and assessment unit; these codes are uniform throughout the project and will identify the same item in any of the publications. The code is as follows:

\begin{tabular}{lr}
\hline & Example \\
\hline Region, single digit & $\mathbf{1}$ \\
Province, three digits to the right of region code & 1154 \\
Total petroleum system, two digits to the right of province code & 115401 \\
Assessment unit, two digits to the right of petroleum system code & $115401 \mathbf{0 2}$ \\
\hline
\end{tabular}


The codes for the regions and provinces are listed in U.S. Geological Survey World Energy Assessment Team (2000).

Oil and gas reserves quoted in this report are derived from Petroleum Exploration and Production Database (Petroconsultants, 1996) and other area reports from Petroconsultants, Inc., unless otherwise noted.

A map, figure 1 of this report, shows boundaries of the total petroleum systems and assessment units; it was compiled using geographic information system (GIS) software. Political boundaries and cartographic representations were taken, with permission, from Environmental Systems Research Institute's ArcWorld 1:3-million digital coverage (1992), have no political significance, and are displayed for general reference only. Oil and gas field centerpoints, shown on this map, are reproduced, with permission, from Petroconsultants (1996). 


\section{Contents}

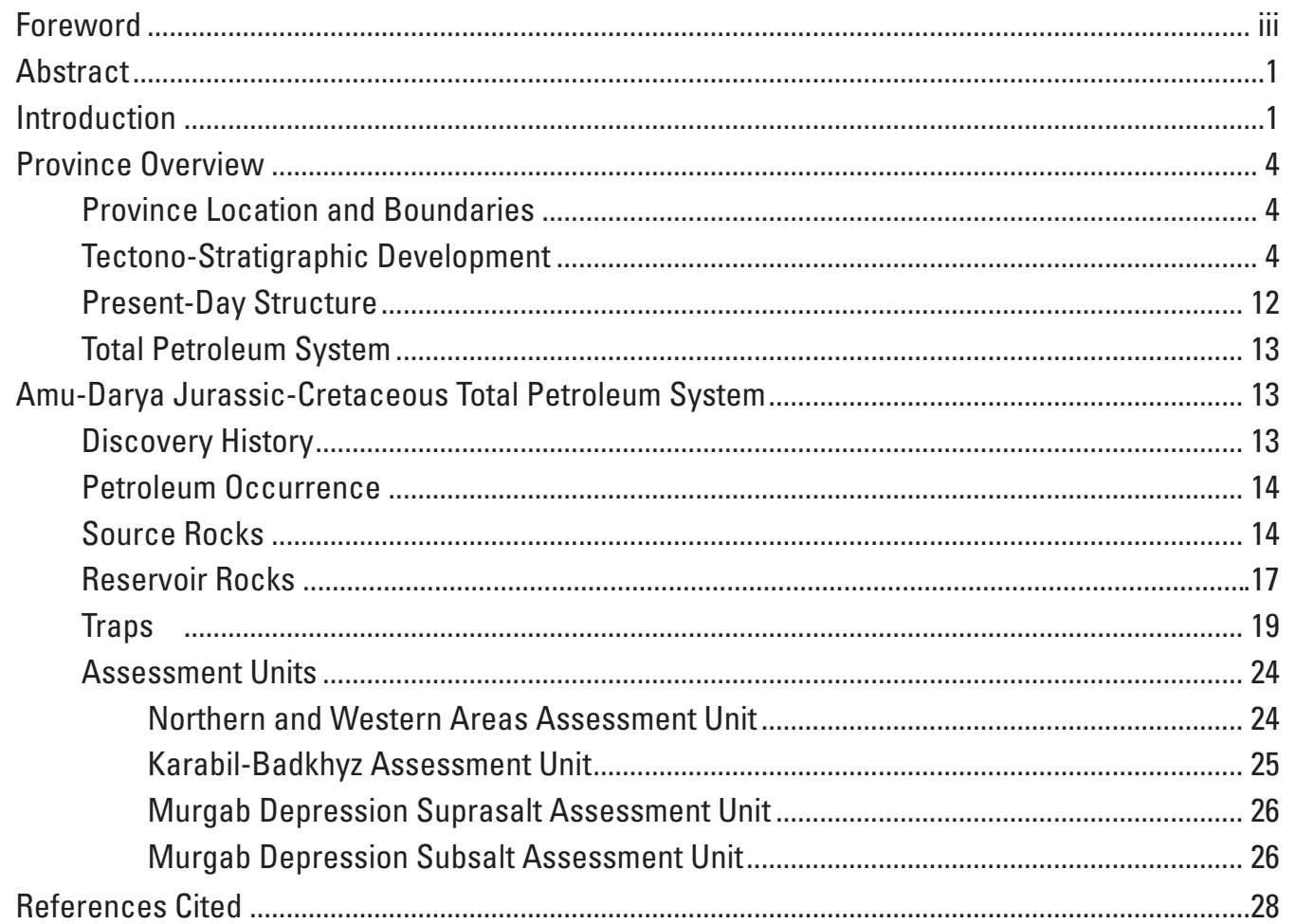

\section{Figures}

1. Total petroleum system and assessment units of Amu-Darya basin ............................... 2

2. Structural map of Amu-Darya basin showing oil and gas fields ...................................... 3

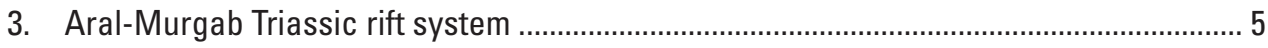

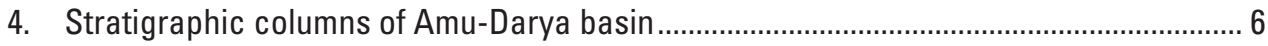

5. Isopach map of Lower-Middle Jurassic rocks of Amu-Darya basin ................................ 7

6. Facies map of Oxfordian rocks of Amu-Darya basin ......................................................... 8

7. Paleogeographic map of Urtabulak-Dengizkul area, northwestern Amu-Darya basin, for Oxfordian time ............................................................................. 9

8. Structural map of Yashlar area, south margin of Amu-Darya basin ................................ 10

9. Isopach and lithofacies map of Upper Jurassic Gaurdak Formation .............................. 11

10. Distribution of average TOC contents in Lower-Middle Jurassic rocks of

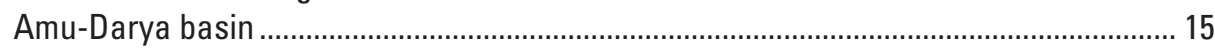

11. Maturation models for northern Khiva-Zaunguz depression, Murgab depression, and Kopet-Dag foredeep ............................................................. 16

12. Amu-Darya Jurassic-Cretaceous total petroleum system events chart........................ 17

13. Isopach and lithofacies map of Shatlyk bed and its stratigraphic analogs

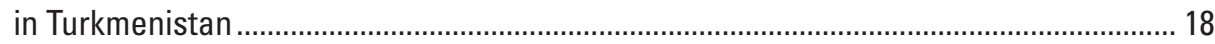

14. Cross section through Gazli gas field, Amu-Darya basin............................................ 19

15. Cross section through Urtabulak gas field, Amu-Darya basin ........................................ 20 
16. Structural map of Dauletabad gas field, Amu-Darya basin.............................................. 21

17. Potentiometric map for Shatlyk Bed of Murgab depression and

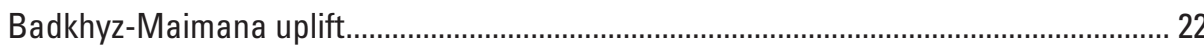

\section{Table}

1. Amu-Darya basin, province 1154 , assessment results summaryAllocated resources. 


\title{
Petroleum Geology and Resources of the Amu-Darya Basin, Turkmenistan, Uzbekistan, Afghanistan, and Iran
}

\author{
By Gregory F. Ulmishek
}

\section{Abstract}

The Amu-Darya basin is a highly productive petroleum province in Turkmenistan and Uzbekistan (former Soviet Union), extending southwestward into Iran and southeastward into Afghanistan. The basin underlies deserts and semideserts north of the high ridges of the Kopet-Dag and Bande-Turkestan Mountains. On the northwest, the basin boundary crosses the crest of the Karakum regional structural high, and on the north the basin is bounded by the shallow basement of the Kyzylkum high. On the east, the Amu-Darya basin is separated by the buried southeast spur of the Gissar Range from the Afghan-Tajik basin, which is deformed into a series of north-south-trending synclinoria and anticlinoria. The separation of the two basins occurred during the Neogene Alpine orogeny; earlier, they were parts of a single sedimentary province.

The basement of the Amu-Darya basin is a Hercynian accreted terrane composed of deformed and commonly metamorphosed Paleozoic rocks. These rocks are overlain by rift grabens filled with Upper Permian-Triassic rocks that are strongly compacted and diagenetically altered. This taphrogenic sequence, also considered to be a part of the economic basement, is overlain by thick Lower to Middle Jurassic, largely continental, coal-bearing rocks. The overlying Callovian-Oxfordian rocks are primarily carbonates. A deep-water basin surrounded by shallow shelves with reefs along their margins was formed during this time and reached its maximum topographic expression in the late Oxfordian. In Kimmeridgian-Tithonian time, the basin was filled with thick evaporites of the Gaurdak Formation. The Cretaceous-Paleogene sequence is composed chiefly of marine clastic rocks with carbonate intervals prominent in the Valanginian, Barremian, Maastrichtian, and Paleocene stratigraphic units. In Neogene time, the Alpine orogeny on the basin periphery resulted in deposition of continental clastics, initiation of new and rejuvenation of old faults, and formation of most structural traps.

A single total petroleum system is identified in the Amu-Darya basin. The system is primarily gas prone. Discovered gas reserves are listed by Petroconsultants (1996) at about 230 trillion cubic feet, but recent discoveries and recent reserve estimates in older fields should increase this number by 40 to 50 trillion cubic feet. Reserves of liquid hydrocarbons (oil and condensate) are comparatively small, less than 2 billion barrels. Most of the gas reserves are concentrated in two stratigraphic intervals, Upper Jurassic carbonates and Neocomian clastics, each of which contains about one-half of the reserves. Reserves of other stratigraphic units - from Middle Jurassic to Paleogene in age-are relatively small. Source rocks for the gas are the Lower to Middle Jurassic clastics and coal and Oxfordian basinal black shales in the east-central part of the basin. The latter is probably responsible for the oil legs and much of the condensate in gas pools. Throughout most of the basin both source-rock units are presently in the gas-window zone. Traps are structural, paleogeomorphic, and stratigraphic, as well as a combination of these types. The giant Dauletabad field is in a combination trap with an essential hydrodynamic component.

Four assessment units were identified in the total petroleum system. One unit in the northeastern, northern, and northwestern marginal areas of the basin and another in the southern marginal area are characterized by wide vertical distribution of hydrocarbon pools in Middle Jurassic to Paleocene rocks and the absence of the salt of the Gaurdak Formation. The other two assessment units are stratigraphically stacked; they occupy the central area of the basin and are separated by the regional undeformed salt seal of the Gaurdak Formation. The largest part of undiscovered hydrocarbon resources of the Amu-Darya basin is expected in older of these assessment units. The mean value of total assessed resources of the Amu-Darya basin is estimated at 164 trillion cubic feet of gas and about 4 billion barrels of petroleum liquids, most of which is condensate.

\section{Introduction}

The Amu-Darya basin (Province 1154) is a rich petroleum province of the former Soviet Union, being second only to West Siberia in reserves and production of natural gas. Most of the province is located in Turkmenistan and Uzbekistan, and its marginal parts extend into Afghanistan and Iran (fig. 1). Discovered petroleum volumes are listed at 40.3 billion barrels of oil equivalent (BBOE) in the Petroconsultants (1996) file, of which only 2 billion barrels are oil and condensate and the 


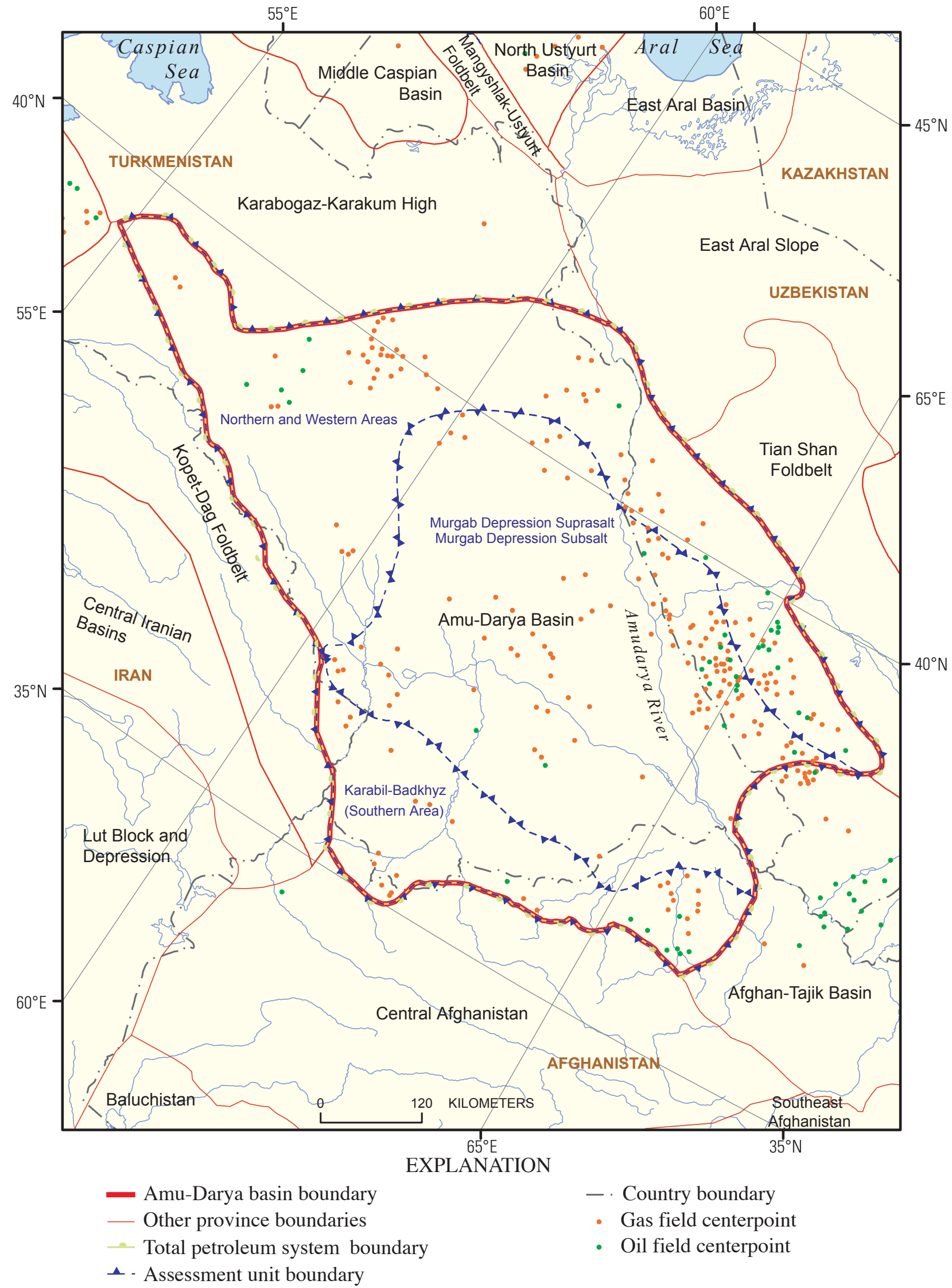

Figure 1. Total petroleum system and assessment units of Amu-Darya basin. 


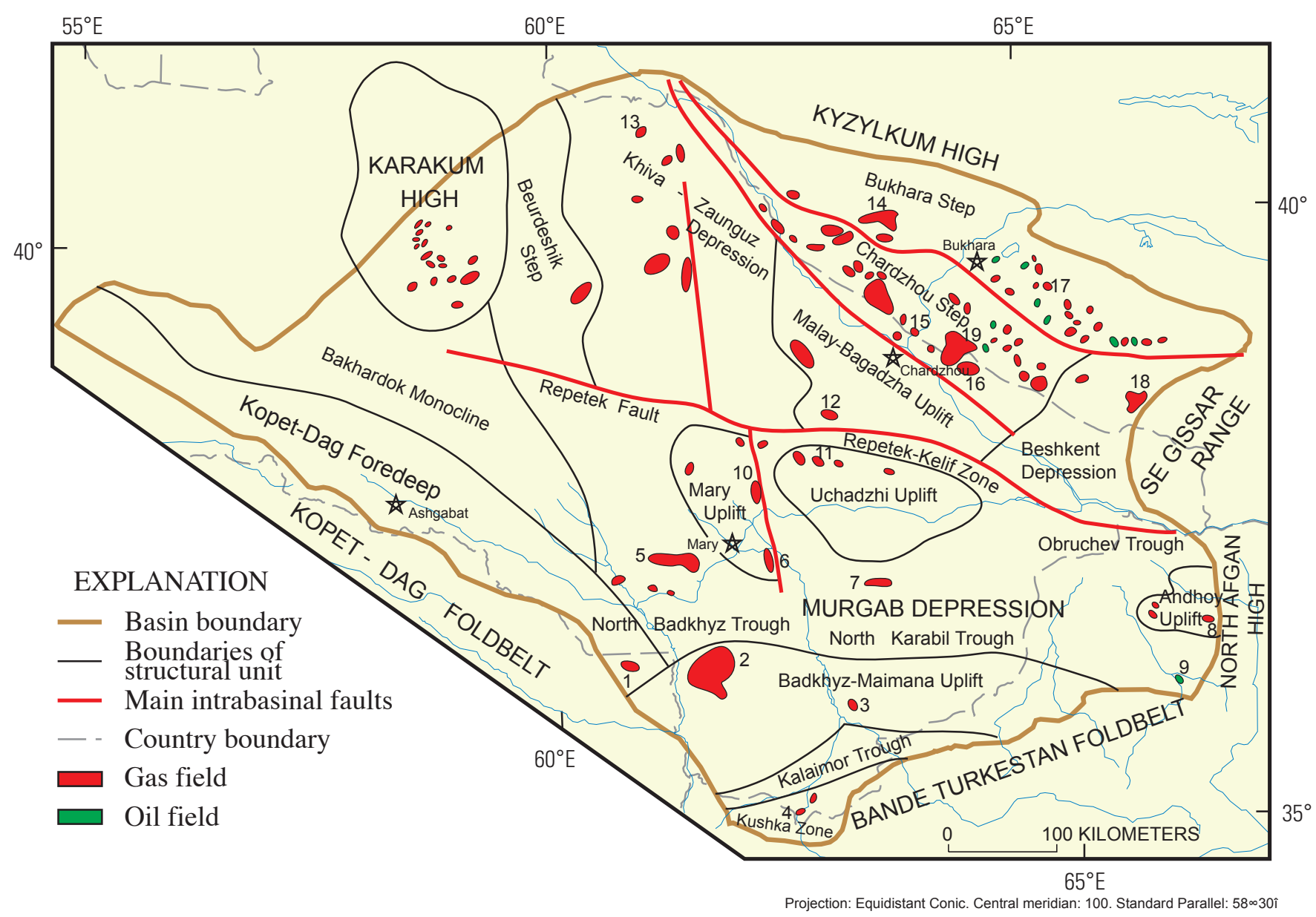

Figure 2. Structural map of Amu-Darya basin showing oil and gas fields (modified from Dikenshteyn and others, 1983). Numbers indicate fields mentioned in text: 1, Khangiran; 2, Dauletabad; 3, Karabil; 4, Islim; 5, Shaltyk; 6, May; 7, Yashlar; 8, Khodzha-Gugerdag; 9, Angot; 10, Bayram-Ali; 11, Uchadzhi; 12, Malay; 13, Achak; 14, Gazli; 15, Kokdumalak; 16, Urtabulak; 17, Setalantepe; 18, Shurtan; 19, Dengizkul.

rest is gas. The basin is ranked 15th on the basis of its original petroleum reserves among the 102 provinces designated for appraisal of undiscovered oil and gas resources by the U.S. Geological Survey (U.S. Geological Survey World Energy Assessment Team, 2000). The basin contains several giant gas and gas condensate fields, the largest of which is the Dauletobad (Dauletobad-Donmez) field with original gas reserves of about 60 trillion cubic feet (TCF).

A single total petroleum system (TPS) was identified in the Amu-Darya basin. The principal discovered gas reserves are in (1) Upper Jurassic reef and shelf carbonates overlain by thick evaporites of the Kimmeridgian Gaurdak Formation and (2) suprasalt clastic rocks of the Hauterivian Shatlyk Bed. Other parts of the sedimentary succession, from the Middle Jurassic to the Upper Cretaceous, are productive on the basin margins where the Gaurdak Formation evaporites are absent. Source rocks for the gas are poorly defined by geochemical methods. Geologic data indicate that probable source rocks are the Lower to Middle Jurassic coaly clastics and coals and the Upper Jurassic marine black shales and marls underlying the Gaurdak Formation. The dominance of gas is related to the gas-prone character of the Lower to Middle Jurassic source rocks and to the great depths of burial and high degree of maturation of the Upper Jurassic source rocks.

The first gas discovery was made in 1953 in the Setalantepe field in the northeastern margin of the basin (fig. 2), which gave further incentive for active exploration efforts in adjacent areas and on the other basin margins. A few relatively small gas accumulations were found before the first major discovery in the basin in 1956-the giant Gazli gas field (fig. 2) with original reserves of about 25 trillion cubic feet (TCF). Other major gas discoveries were mostly made in the 1960s and 1970s. However, some large and giant fields were found in later years, notably the Kokdumalak field with oil and gas reserves of about 2 billion barrels of oil equivalent (BBOE) and the Yashlar field with gas reserves believed to be in the 15 to 35 TCF range (fig. 2). Large-scale gas production began after pipelines to cities of the Urals and central regions of European Russia had been built. By 1980, the basin was producing gas at a rate of more than $3.5 \mathrm{TCF} /$ year. 
Four assessment units (AU) were identified in the Amu-Darya basin. One AU encompasses several structural units in the northern and western marginal areas of the basin, where evaporites of the Upper Jurassic Gaurdak Formation are absent. Another AU embraces the southern basin margin, south of the pinch-out zone of the Gaurdak Formation. The other two AU are stratigraphically superposed; they occupy the central basin area and are separated stratigraphically by salt and anhydrite of the Gaurdak Formation. The lower of these two units includes Lower to Middle Jurassic clastic and Upper Jurassic carbonate rocks below the salt, and the upper one includes Cretaceous-Tertiary clastic and carbonate rocks above the salt.

\section{Province Overview}

\section{Province Location and Boundaries}

The Amu-Darya basin occupies desert and semidesert areas of southeast Turkmenistan, southwest Uzbekistan, and northwest Afghanistan; a small part of the basin is located in Iran (fig. 1). The basin area exceeds $400,000 \mathrm{~km}^{2}$, of which $360,000 \mathrm{~km}^{2}$ are in Turkmenistan and Uzbekistan.

The Amu-Darya basin is bounded on the southwest by the Kopet-Dag foldbelt (figs. 1, 2), which is composed of deformed Jurassic and Cretaceous carbonate and clastic rocks that, in the southwestern part of the foldbelt in Iran, unconformably overlie Triassic and Paleozoic rocks. The boundary follows the frontal fault of the Kopet-Dag, which has a substantial dextral strike-slip component (Lyberis and Manby, 1999). Mesozoic rocks of the Kopet-Dag were deposited in a marginal sea of the northern Tethys ocean. Deformation occurred in Miocene-Pliocene time due to closing of the marginal sea and collision of the Iranian block with the southern margin of Eurasia (Zonenshayn and others, 1990).

The south boundary of the basin is along the north slope of the Bande Turkestan foldbelt, which is a mountain range reaching elevations of more than 3,000 m. Several kilometers of Permian and Triassic clastics, carbonates, and volcanics of the foldbelt overlie older Paleozoic metamorphic rocks and are unconformably overlain by less deformed Jurassic to Paleogene rocks. The Triassic sequence, especially the Upper Triassic, probably was deposited in a rift basin that formed on the Eurasian continental margin behind the magmatic arc of the Hindu Kush and Parapamisus (Brookfield and Hashmat, 2001). Folding and uplift took place in latest Triassic time, followed by deposition of Jurassic-Paleogene rocks on the stable passive margin. Neotectonic deformation related to collision of Eurasia with the Indian subcontinent began in latest Oligocene time and continues to the present, with the deformational pattern generally following the pre-Jurassic structural grain.
To the east, the Amu-Darya basin adjoins the Afghan-Tajik (South Tajik, Surkhan-Vakhsh) basin (fig. 1). The two basins formed a single basin until Miocene time, and their JurassicOligocene stratigraphy is similar. Starting in the Miocene and extending to the present, the Afghan-Tajik basin was deformed by the northward protrusion of the Pamir block. The resulting east-to-west compression produced a series of north-striking anticlinoria and synclinoria that are underlain by thrusts with the principal detachment surface along the Upper Jurassic salt (Loziev and others, 1984; Bekker, 1996). The synclinoria were filled with Neogene-Quaternary orogenic molasse clastics as much as several kilometers thick. The thrusting does not extend into the Amu-Darya basin. On the south, the north-south-trending structures of the Afghan-Tajik basin are cut by a wrench fault that separates them from the North Afghan high. The boundary between the Amu-Darya and Afghan-Tajik basins extends along the western slope of the southwestern spur of the Gissar Range (southern range of the Tian Shan), which is the westernmost anticlinorium of the Afghan-Tajik basin (figs. 1, 2).

On the northern side, the Amu-Darya basin is bounded by Paleozoic metamorphic and igneous rocks of the Kyzylkum high, which in places crop out on the surface, but in most of the area are overlain by a thin veneer of Mesozoic-Tertiary deposits. The Paleozoic formations extend from the Kyzylkum high into the neotectonic Tian Shan Mountains where they were studied by generations of Soviet geologists. Basically, Paleozoic rocks of the Kyzylkum high and Tian Shan indicate Hercynian closing of two oceanic basins due to consecutive collision of the Karakum (in Middle to Late Carboniferous time) and Tajik (in Early Permian time) microcontinental blocks with the southern margin of the Caledonian Kazakhstan continent (Zonenshayn and others, 1990). The principal orogeny and intrusion of granite plutons took place in Early Permian time.

The northwest boundary of the Amu-Darya basin crosses the Karakum regional high (fig. 2), on the crest of which Paleozoic basement rocks are at depths as shallow as 1,600 to 2,200 m. Hydrocarbon fields are present only on the crest of the high and on its southern and eastern slopes; these productive areas are included in the basin. Neither fields nor oil and gas shows have been found on the northern and western slopes of the high.

\section{Tectono-Stratigraphic Development}

The Amu-Darya basin is a large Jurassic-Tertiary depression that overlies the Hercynian (late Paleozoic) basement and Triassic (possibly Late Permian-Triassic) rift system. The basin is the largest depression of the epi-Hercynian Turan platform (part of the Hercynian accreted terrane east of the Caspian Sea covered by Mesozoic-Cenozoic sedimentary rocks). The composition of the basement in the deep basin interior is poorly known; extrapolation from the basin margins indicates that it probably consists of various tectonic terranes 
accreted during the Hercynian closing of oceanic basins. The Hercynian basement includes two large Precambrian continental massifs (microcontinents in pre-collisional structure) to the north and to the south. In the north, the Karakum massif was penetrated by wells in its western part, on the Mesozoic Karakum high (fig. 2) where the Jurassic-Cretaceous sedimentary sequence overlies metamorphosed volcanic and sedimentary rocks that include amphibolite slates with a K-Ar age of $585 \pm 25$ million years $(\mathrm{Ma})$. The rocks are cut by granites ranging in age from Silurian (425 Ma) to Carboniferous (302 Ma) (Maksimov, 1992). The microcontinental block extends eastward into the Tian Shan foldbelt (figs. 1,2), north of the Gissar Range, and may have been connected with the Tarim block in northwest China (Zonenshayn and others, 1990). The southern of the two massifs, the Tajik massif, underlies the northern part of the Afghan-Tajik basin and extends into the Amu-Darya basin. It is identified primarily on the basis of gravity and magnetic data (Maksimov, 1992). Proterozoic basement rocks of the massif crop out locally in the southern part of the Gissar Range. Silurian to Carboniferous carbonates and clastics are widespread there and are interpreted as deposits of the northern passive margin of the Tajik microcontinent (Zonenshayn and others, 1990). The central part of the Gissar Range includes ophiolites that mark the collision zone, rocks of the Carboniferous volcanic arc, and Permian post-collisional granites. The rest of the Amu-Darya basin basement consists of various oceanic complexes, among which Carboniferous basic volcanics are widespread and produce characteristic positive linear anomalies in the magnetic field.

The taphrogenic stage of development of the Amu-Darya basin occurred during the Late Permian and Triassic, after the Hercynian orogeny and subsequent denudation of the resulting mountainous terrain. The basement was broken by a series of rifts, and the rift grabens accumulated thick (as much as several kilometers as interpreted from geophysical data) clastic sediments. Because of deep burial, the location of the rift system is poorly known. One of the recent models, shown in figure 3 , is based on limited seismic data (primarily deep seismic sounding) and indicates the presence of a rift system trending oblique to the Neogene Kopet Dag foldbelt (Khain and others, 1991). The existence of another near latitudinal graben-rift is postulated in the deepest southeastern part of the basin (Maksimov, 1992). A third rift that was deformed and uplifted first in the latest Triassic and subsequently during the Alpine orogenic event in Neogene-Quaternary time forms the Bande Turkestan Ridge that bounds the Amu-Darya basin on the south (fig. 2). The rift fill of the Bande Turkestan Ridge, as much as $6 \mathrm{~km}$ thick, is composed primarily of Permian-Triassic coarse to fine clastic rocks with minor Middle Triassic limestone beds and Ladinian-Norian tuffs and lavas (Brookfield and Hashmat, 2001).

The basinal sedimentary cover of the Amu-Darya basin unconformably overlies various older rocks. During Jurassic through Eocene time, sedimentation occurred on the passive margin of a marginal sea, north of the Tethyan Mesozoic volcanic arcs. Lower and Middle Jurassic rocks at the base

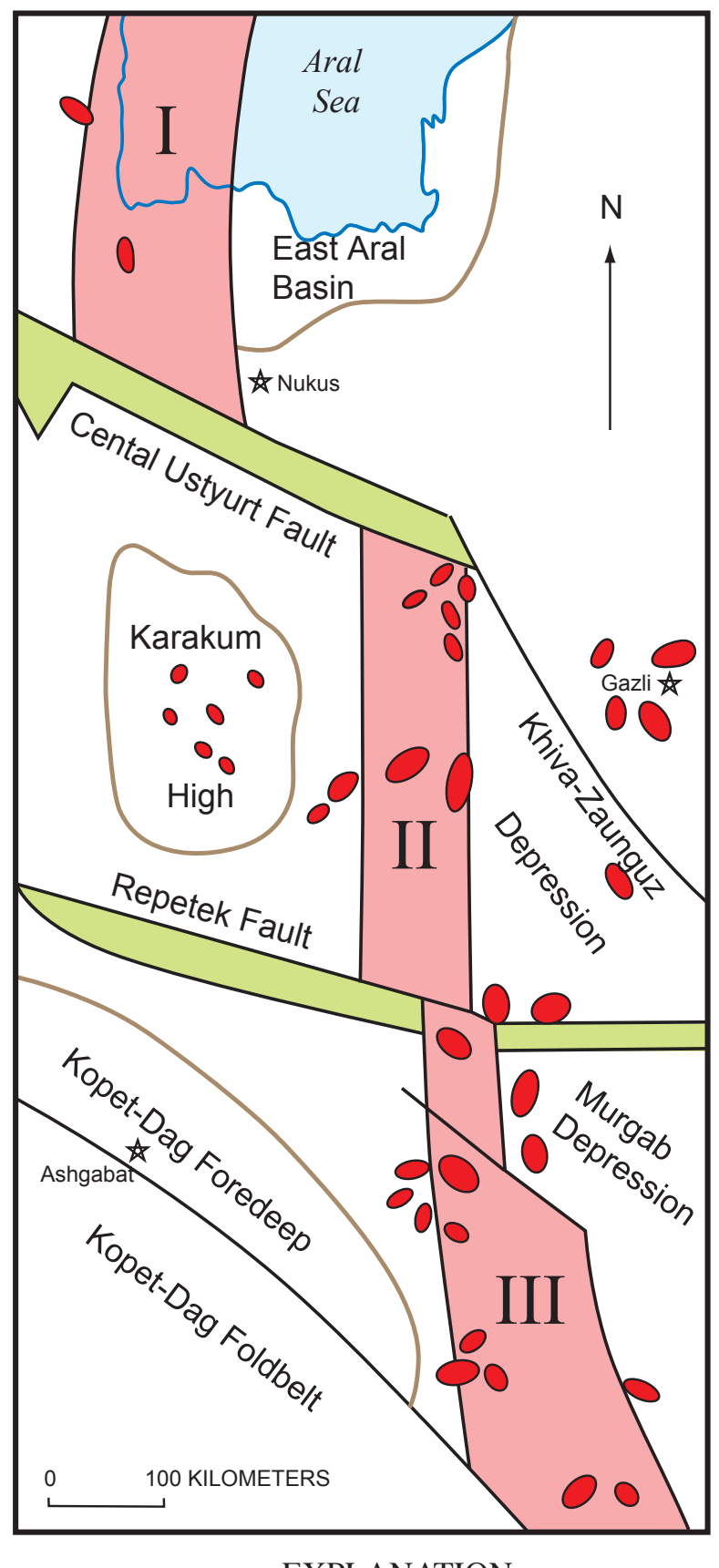

EXPLANATION

Rift

Transform fault and associated zone of uplift

Oil and gas fields

Main faults

Boundaries of main

Mesozoic structures

Figure 3. Aral-Murgab Triassic rift system (modified after Khain and others, 1991). Rifts: I, Aral; II, East Zaunguz; III, TedzhenMurab. 
of the passive margin sequence have been drilled primarily on the basin margins and have not been fully penetrated by wells in the central basin. In general, Lower-Middle Jurassic strata are chiefly composed of continental clastic rocks (fig 4). Marine beds appear in the upper Bajocian-Bathonian interval; their number and thickness increase southward. Coarse clastics are mainly confined to the basal Lower Jurassic section that also contains coal beds (Alekseev and others, 1990). Only thin coals are present in younger rocks. Tuffs and diabases were encountered in several wells near deep faults along the northeastern basin margin where a graben filled with Lower Jurassic to basal Middle Jurassic rocks has been identified. Another Early Jurassic graben is known in northern Afghanistan on the Badkhyz-Maimana uplift (fig. 2) (Brookfield and Hashmat, 2001). The presence of similar pre-Bajocian grabens is inferred in deeper parts of the basin on the basis of limited seismic data (Maksimov and others, 1986). The Lower-Middle Jurassic sequence laps onto basement highs, and its lower part pinches out on the slopes of the highs. Thickness of the sequence is poorly constrained by the low resolution of seismic data at great depths. In the deepest part of the basin it is interpreted to be about $2 \mathrm{~km}$ thick (fig. 5), but it thins to $500 \mathrm{~m}$ or less on the northern basin margin and is depositionally absent on the Badkhyz-Maimana uplift along the southern margin. Lower-Middle Jurassic rocks are present in Afghanistan north and south of the uplift, but their thickness is known only in marginal areas where it does not exceed several hundred meters (Bratash and others, 1970).

Marine transgression began in latest Bathonian or early Callovian time. After deposition of the basal shale unit, the carbonate sedimentation commenced and continued into Oxfordian time (fig. 4). During the Callovian-Oxfordian interval, the Amu-Darya basin was topographically partitioned into the deep-water sea that occupied the southeastern basin area and shallow-water shelves on its margins (fig. 6). A complex of barrier reefs, pinnacle reefs, and atolls formed along the shelf edge and in marginal areas of the deep-water basin. The thickest and most hydrocarbon-productive parts of the reef bodies are composed of middle and upper Oxfordian limestones. This reef complex contains nearly one-half of the discovered hydrocarbon reserves of the basin and much of its estimated undiscovered resources. The total thickness of the

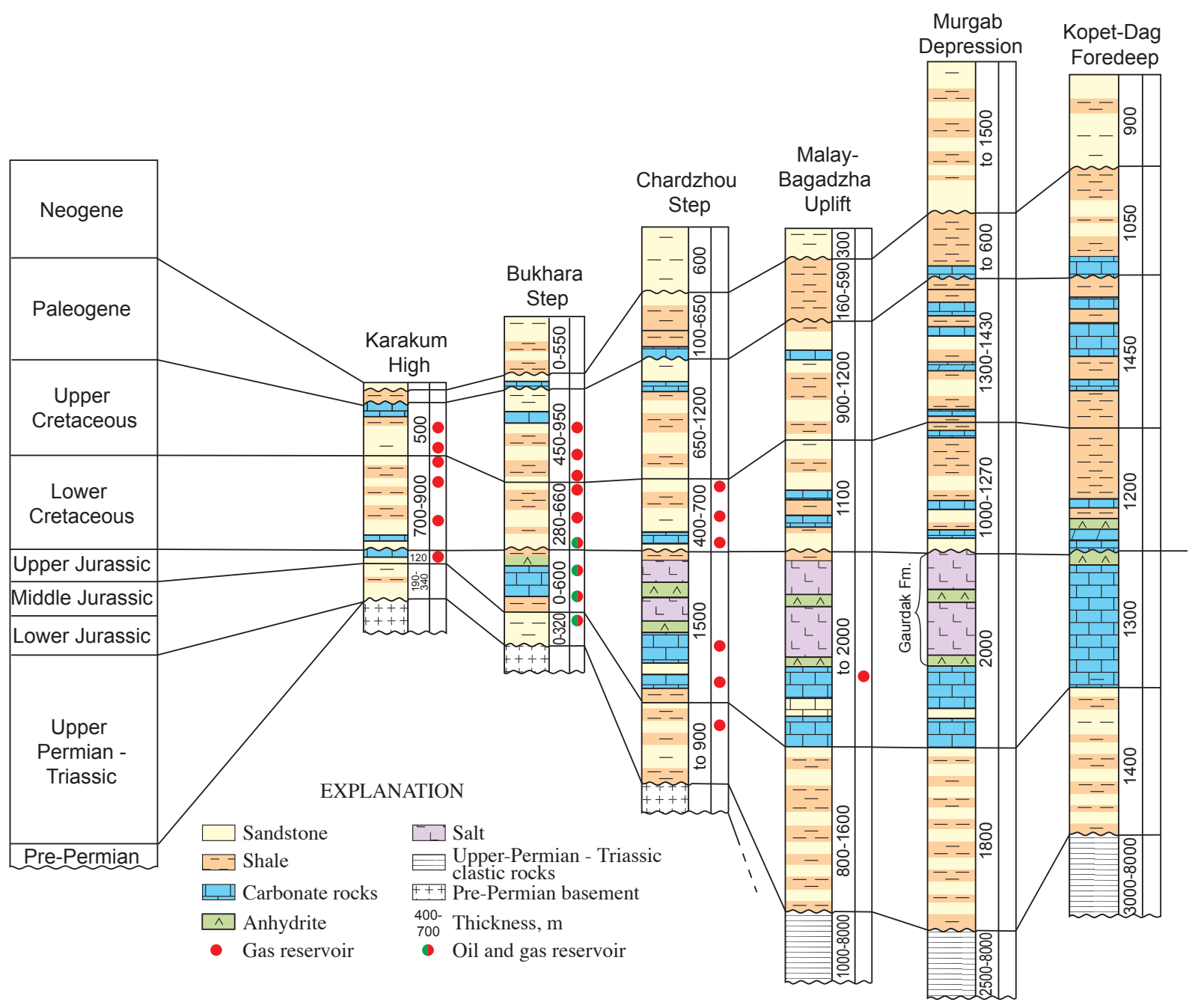

Figure 4. Stratigraphic columns of Amu-Darya basin (modified from Yermolkin, 1986). For location of structural units, see figure 2. 


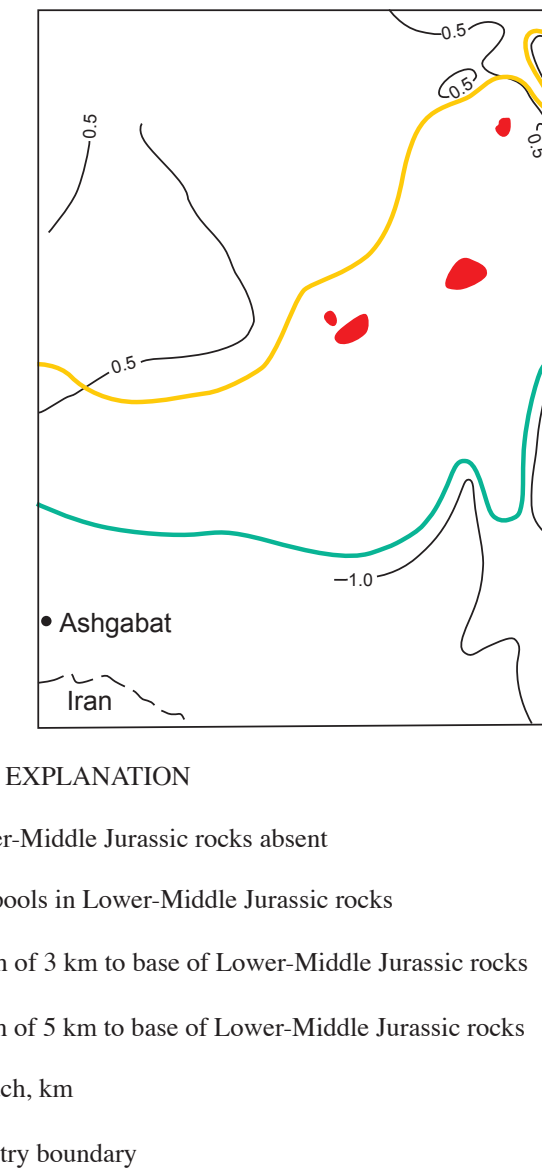

_ Country boundary
Figure 5. Isopach map of Lower-Middle Jurassic rocks of Amu-Darya basin (modified after Maksimov and others, 1986).
Upper Jurassic carbonate sequence reaches 500-600 m in the reef facies zone, of which about one-half is composed of reef limestones. The thickness decreases to 100 to $150 \mathrm{~m}$ in the nearshore zone, and the sequence pinches out at the basin margin.

The Callovian to Oxfordian shelf sequence is composed of various shallow-water facies; including oolitic, detrital, and algal limestones and dolomitic limestones; small nearshore Callovian carbonate buildups; argillaceous limestones and marls; and local beds of anhydrite in the middle-upper Oxfordian section. Siliciclastic material is present and is locally dominant along the northern basin margin.

The deep-water basinal facies is poorly known because it is deeply buried and has been penetrated in only a few wells located mostly in the easternmost area of its distribution. The lower-middle Oxfordian section is composed of dark-gray, thin- to medium-bedded, bituminous, argillaceous limestones. The upper Oxfordian section consists of black, thinly laminated, highly organic rich argillaceous limestones and calcareous shales and siltstones with an admixture of volcanic ash (Fortunatova, 1985). These rocks, which contain ammonites and other planktonic fossils, are characterized by high readings on gamma-ray logs and are known as the radioactive bed. The total thickness of the Upper Jurassic carbonate sequence in the basinal facies is about 200 to $250 \mathrm{~m}$.
The reefs and associated rocks are best known on the northeast margin of the Amu-Darya basin, primarily on the Chardzhou structural step in Uzbekistan (fig. 2) where they contain the bulk of the oil and gas reserves (fig. 7). Upper Jurassic carbonates, including reef facies, crop out on the southeast spur of the Gissar Range just east of the basin border, which provides important data for stratigraphic correlations. The strata composing the lower 50-100 $\mathrm{m}$ of the section in the reef facies belt, which are middle Callovian in age, consist of thin- to medium-bedded, dark-gray, argillaceous limestones that are designated as productive horizon XVI in the local production nomenclature. Deposition of these strata preceded the initiation of reef growth. Reef facies appear in the overlying section, which mainly consists of detrital limestones 120 to $160 \mathrm{~m}$ thick. This section (productive horizon XVpr) is late Callovian to middle Oxfordian in age; in places it includes algal-bryozoan reefs 30 to $50 \mathrm{~m}$ high (Abdullaev, 1999).

Major reef development took place during late Oxfordian and probably early Kimmeridgian time when differentiation of basin topography into the deep-water depression, high-standing reefs, and back-reef shelf and lagoons reached its maximum. The principal reef builders were corals and algae. The extended semicircular barrier reef, which separated the shelf from deep-water basin (fig. 7), is dissected into segments 4 to $8 \mathrm{~km}$ long by tidal channels 50 to $100 \mathrm{~m}$ deep (Goryunov and Ilyin, 1994). The channels are from a few hundred meters to $1.5 \mathrm{~km}$ 
wide; they are filled with, and overlain by, younger evaporites. The channels play an important role in formation of hydrocarbon traps in the barrier reef complex. A number of solitary reef buildups (pinnacles and atolls) formed inside the deep-water basin. The upper Oxfordian-lower Kimmeridgian reef section reaches $250 \mathrm{~m}$ in thickness; it includes $\mathrm{XVr}$ and $\mathrm{XVnr}$ productive horizons of the local nomenclature. The reefs are commonly surrounded by carbonate debris sheets. Basinward, the reef-carbonate section grades into highly organic rich black shale (radioactive bed) that covers the basin floor and overlaps some of the reefs that apparently drowned during the maximum sea-level rise. Back-reef facies that are developed landward from the reef zone consist of various shallow-water carbonates interbedded with anhydrite. Farther landward, the carbonate section includes siliciclastic material that was derived from adjoining land (fig. 6).

From the Chardzhou step, the barrier reef extends westward and southwestward where it separates the extensive northern shelf from the deep-water basin (fig. 6). The exact location of the reef is not well known because few wells have penetrated below the Upper Jurassic salt in that area. Pinnacle reefs inside basinal facies have not been reliably identified,

Figure 6. Facies map of Oxfordian rocks of Amu-Darya basin in former Soviet Union (compiled from Maksimov and others, 1986, and Abdulaev and others, 1991). Position of southern barrier reef is poorly constrained by data.

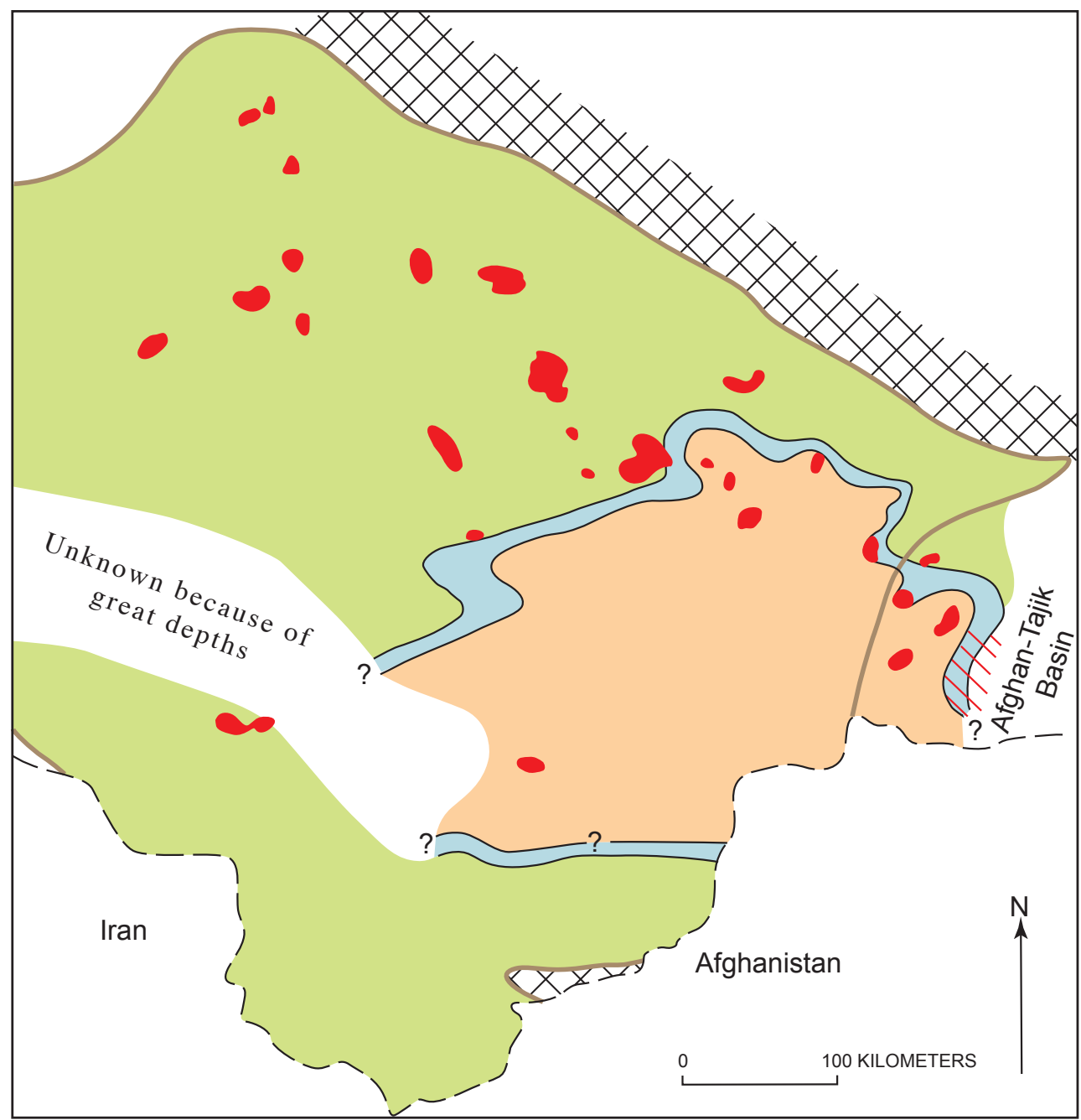

\section{EXPLANATION}

Deep water basinal facies including solitary reef buildups

Back-reef, shallow shelf, and nearshore facies

Barrier reef

Main fields in Oxfordian carbonate reservoirs

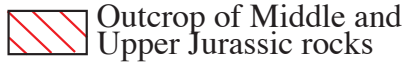

XUpper Jurassic rocks absent

Amu-Darya basin boundary

— - Country boundary 
probably because of great depths, but their presence is inferred on the basis of limited drilling and seismic data (Abdyllaev and others, 1991; Maksimov and others, 1986). Farther southwest, the barrier reef plunges to depths exceeding $5 \mathrm{~km}$, and its location is not known.

The location and morphology of the reef zone along the south margin of the Amu-Darya basin are poorly known. Upper Jurassic carbonates are at depths exceeding $4 \mathrm{~km}$, and the quality of seismic data available in the former Soviet Union was inadequate to map the reef bodies below the thick evaporites. More recent seismic data acquired by the Bridas Co. (Argentina) are of higher quality, but are not publicly available. Oxfordian limestones and dolomitic limestones of probable reef origin were penetrated by a few wells between the Dauletabad and Shatlyk fields (fig. 2), and in the Dauletabad field wells penetrated back-reef facies (Allanov and others, 1985). Reefs in this area were also inferred from seismic data. Farther east, well 8 of the Yashlar field (fig. 2), which was drilled by the Bridas Co., tested about 10 million cubic feet of gas per day from Oxfordian carbonates at a depth between 4.5 and $5 \mathrm{~km}$. The morphology of the reef bodies is unclear. Seismic data indicate that the Late Jurassic structure of the southern slope of the Murgab depression (fig. 2) consists of two linear uplifted blocks trending east to west and separated by structural lows (O'Connor and Sonnenberg, 1991) (fig. 8). The uplifted blocks are apparently covered by carbonate bank deposits that contain reefs (Kleshchev and others, 1991). Barrier reefs may be located along the block margins, and basinal facies probably fill the lows. To the east, the barrier reef extends into northern Afghanistan. It is located northwest and north of the North Afghan high (fig. 2), but its exact position is not known. On the crest of the North Afghan high, the entire Upper Jurassic section is absent due to nondeposition, and Cretaceous rocks unconformably overlie the Paleozoic basement or thin Lower-Middle Jurassic and (or) Triassic rocks (Bratash and others, 1970).

Evaporites of the Kimmeridgian-Tithonian Gaurdak Formation overlie older Upper Jurassic carbonate rocks in the central part of the Amu-Darya basin where the formation is more than 900 m thick (fig. 9). Generally, the Gaurdak Formation consists of two salt layers that are underlain, and also separated, by anhydrite strata. A thinner (15 m or less) anhydrite bed lies at the top of the formation. Both lower and middle anhydrites include carbonate beds that are mostly limited to the marginal parts of the basin. Thickness of the lower anhydrite is commonly 10 to $30 \mathrm{~m}$ on top of the reefs, and it increases to 100 to $200 \mathrm{~m}$

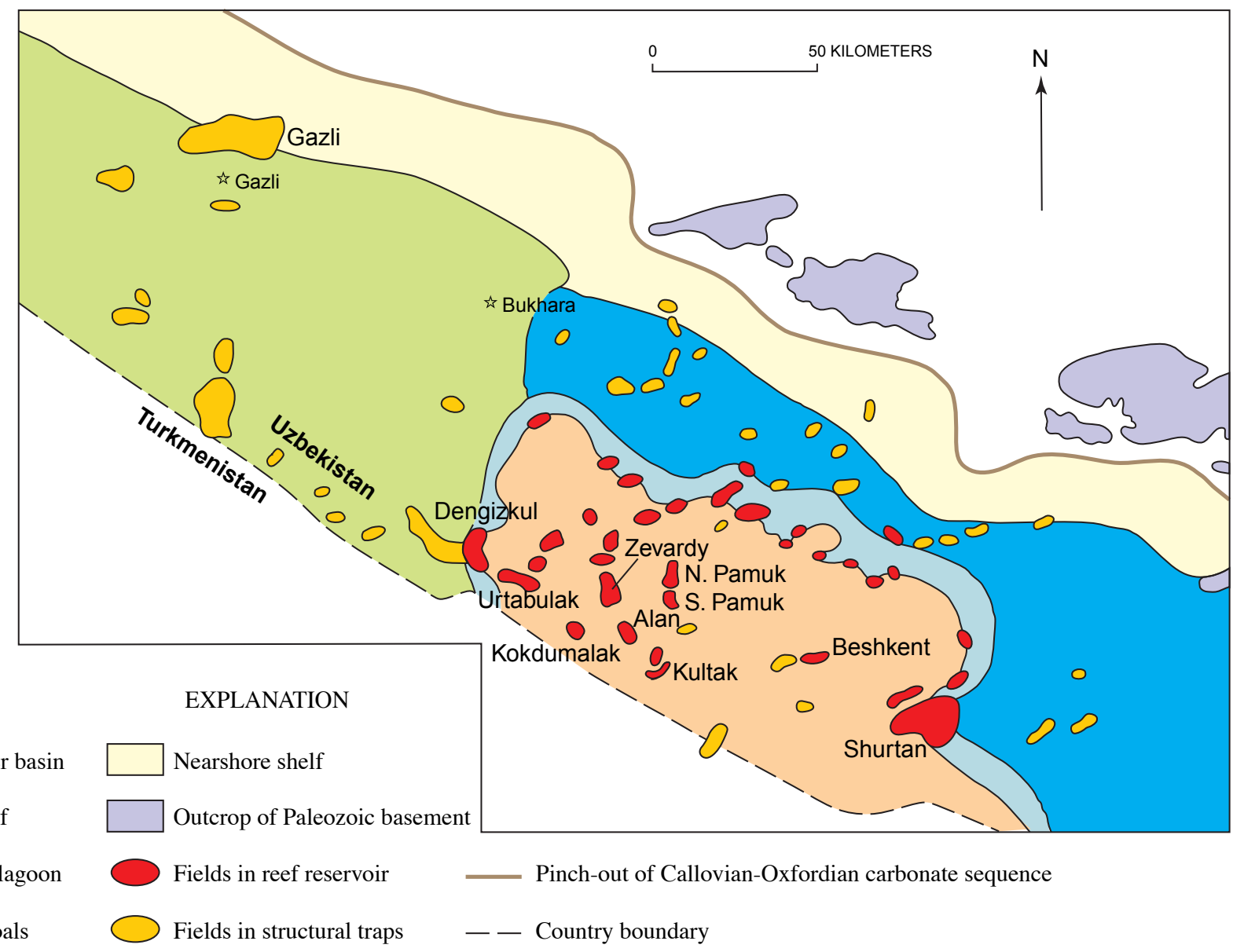

Figure 7. Paleogeographic map of Utrabulak-Shurtan area in Uzbekistan, northwestern Amu-Darya basin, for Oxfordian time (modified after Ibragimov and Ivanov, 1984). 


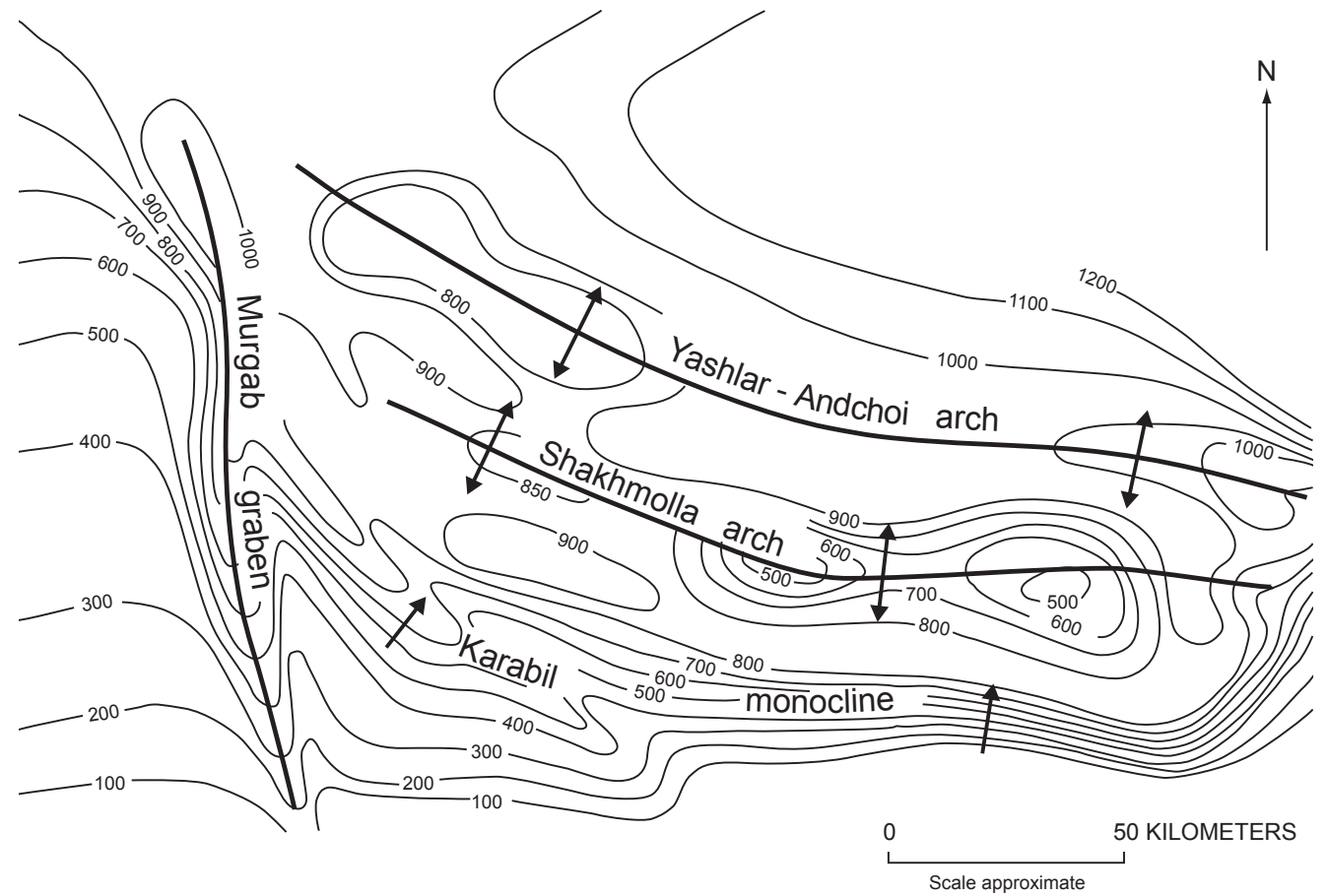

EXPLANATION
Figure 8. Structural map of Yashlar area, south margin of Amu-Darya basin (modified after O'Connor and Sonnenberg, 1991). Yashlar field (location 7 in fig. 2) is in western part of Yashlar-Andchoi arch.

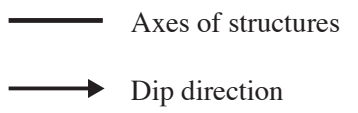

on the reef slopes (Goruynov and Ilyin, 1994; Ilyin and Fortunatova, 1988). Farther into the basin, the thickness of the anhydrite bed decreases again to about $50 \mathrm{~m}$. Zones of the anhydrite bed, which adjoin the reefs, are used as an exploration tool for identifying the location of reef bodies (Gorynov and Ilyin, 1994; Vakhabov, 1986). However, these zones of thick anhydrite hinder interpretation of seismic data because their seismic characteristics are similar to that of underlying carbonates.

The lower salt layer fills the topographic irregularities inherited from Oxfordian time; it is thin or absent on top of the reefs and on the back-reef shelf and thickens abruptly over Oxfordian deep-water deposits. The upper salt layer is less variable, being several hundred meters thick in the central basin area and thinning gradually toward the basin margins. Both salt layers locally contain anhydrite beds and potassium salt beds. In the marginal zone of the Gaurdak Formation, the salt completely pinches out, and the formation is composed of alternating carbonate and anhydrite beds with a variable amount of clastic rocks that are more abundant on the north basin margin (Khudaykuliev, 1986).

The Gaurdak Formation extends into the Afghan-Tajik basin, where it is poorly known because of its deep burial in synclinoria and because of complex structure in anticlinoria. The formation is absent on the Karakum and North Afghan highs and in most of the Kopet-Dag foredeep (figs. 2, 9). Over almost the entire area of its distribution, salt of the Gaurdak Formation is not deformed by halokinesis. The only exception is a narrow linear zone known as the Repetek-Kelif zone, which extends along the Repetek deep fault probably with a strike-slip component, where the salt is deformed into domes (figs. 2, 9).
Evaporites of the Gaurdak Formation are conformably overlain by the Karabil Formation, which is composed of red clastic rocks 100 to $300 \mathrm{~m}$ thick. The only fossils in the red beds are euryhaline ostracods of a wide stratigraphic range. The rocks were probably deposited in a lagoonal to alluvial environment. The formation, believed to be late Tithonian or late Tithonian-earliest Berriasian in age (Beznosov and others, 1987) is absent in marginal parts of the basin.

In the Kopet-Dag foldbelt (fig. 2), Upper Jurassic evaporites and red beds of the Amu-Darya basin grade into bedded marine limestones in the Kimmeridgian part of the section and into massive limestones and dolomites with inclusions of anhydrite in the Tithonian part (Amanniyazov, 1989). These shallow-water carbonate rocks, probably partly of reef origin, separated open Tethyan seas to the south from the Amu-Darya evaporite lagoon to the north. This paleogeographic situation is closely similar to that in the Kimmeridgian-Tithonian salt basin in the eastern North Caucasus (Ulmishek, 2001).

Lower Cretaceous strata unconformably overlie Paleozoic to Upper Jurassic rocks on the basin margins; however, the unconformity is minor or absent in the central basin area (Pashaev and others, 1993). Neocomian (Berriasian-Barremian) rocks were deposited in conditions ranging from marine to continental. Marine carbonates dominate in the Kopet-Dag Range and adjacent foredeep (figs. 2, 4). Northward, to the Karakum high, the carbonates grade into marine clastic rocks. East of the Karakum high and Kopet-Dag foredeep, the section is composed of alternating marine, lagoonal, and continental rocks with the proportion of marine rocks decreasing eastward. In the eastern part of the basin, marine rocks are absent, and the section consists of lagoonal to continental red and variegated 
clastics with beds of dolomite, anhydrite, and salt. Coarse alluvial clastics transported from uplifts to the southwest compose the Neocomian section in the area of the Iranian gas fields (MoussaviHarami and Brenner, 1992), and more distal facies are present in the Daultabad gas field and adjoining areas (fig. 2). Continental clastics are also prominent in other parts of the southern basin margin, including Afghanistan. A prominent sandstone interval in the Neocomian section is the Hauterivian Shatlyk Bed, which contains the largest gas reserves in Turkmenistan, including the supergiant Dauletabad gas field. The Shatlyk Bed is of deltaic origin and is present in the western and central areas of the Murgab depression and on its slopes with thickness of 10 to $130 \mathrm{~m}$ (Tashliev and others, 1985).

The bed is composed of red and brown sandstones with interbedded claystone layers. In the eastern part of the Murgab depression (fig. 2), the sandstones grade laterally into a 20- to 60-m-thick salt mixed with sand grains (Pashaev and others, 1993; Kryuchkov, 1996). Salt in this part of the stratigraphic section extends as far east as northwestern Afghanistan (Bratash and others, 1970).
Marine transgression covered the entire Amu-Darya basin in late Barremian time. Aptian-Albian rocks are represented by marine shales, siltstones, and sandstones locally with carbonate beds that are most common in the middle Aptian. The total thickness of Lower Cretaceous rocks exceeds 1,200 m in the Murgab depression and Kopet-Dag foredeep and gradually decreases toward the basin margins.

Upper Cretaceous rocks are dominantly of marine origin; lagoonal red beds and anhydrite are present only in the southeastern part of the Chardzhou step (fig. 2). Limestones and marl compose most of the section, except for the Cenomanian clastic interval, in the Kopet-Dag foredeep and on the Karakum high. To the east, carbonates grade into clastic rocks consisting of mostly shales and siltstones in the central basin and coarser lithologies on the basin margins. Minor limestone and marl beds are present in the Campanian and Maastrichtian strata.

Figure 9. Isopach and lithofacies map of Upper Jurassic Gaurdak Formation (modified after Gavrilcheva and Pashaev, 1993). Columnar sections show composition of formation in identified lithofacies zones.

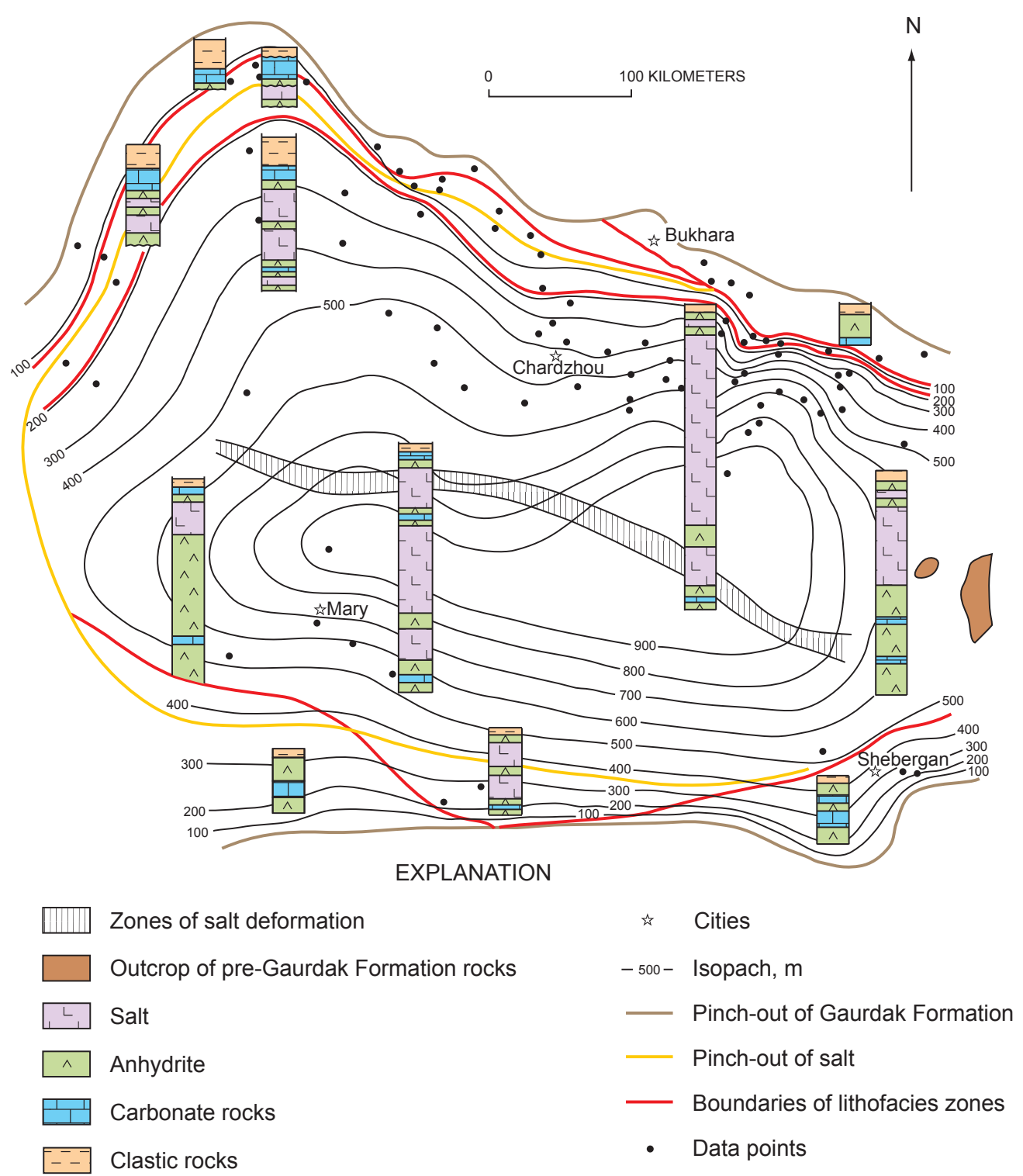


Paleogene (Paleocene to middle Oligocene) rocks are at the top of the sedimentary fill of the Amu-Darya basin. Lower Paleocene (Danian) clastics and carbonates are preserved only in the western and southern areas of the basin and were removed by pre-middle Paleocene erosion elsewhere. The middle and upper Paleocene strata (Bukhara Formation) are composed chiefly of shallow-water carbonate rocks containing beds of clastics and anhydrite. The proportion of clastic rocks increases northward and northwestward, whereas anhydrite beds and anhydrite inclusions in other lithologies are present mainly in the southern basin areas. The Eocene-middle Oligocene section is composed mainly of gray and variegated shales and siltstones, with sandstones commonly present in the southern part of the basin. Carbonates and marls are present throughout the sequence, being more abundant in the western areas. Beds of basalt, andesite, and tuff have been penetrated by wells in the upper Eocene section of the Badkhyz-Maimana uplift (fig. 2). Paleogene rocks are more than $2 \mathrm{~km}$ thick in the Kopet-Dag foredeep, 500 to $800 \mathrm{~m}$ thick in the Murgab depression, and only tens to a few hundred meters thick in the basin marginal areas.

Structural movements of the Amu-Darya basin during the basinal stage of development (Jurassic through Paleogene) are characteristic of block-type platform tectonics. Structural highs, such as the Karakum high, Badkhyz-Maimana uplift, North Afghan high, and smaller uplifts experienced slower subsidence and occasional positive movements that resulted in local disconformities and the absence of parts of the sedimentary sequence. Maximum subsidence took place in the central part of the basin (Murgab depression and areas adjacent to the north) and in the present-day Kopet-Dag foredeep (fig. 2).

Alpine orogenic movements in mountain ranges bordering the Amu-Darya basin began in late Oligocene time owing to collision of the Indian and Arabian continental plates with the Eurasian margin, and tectonism progressively increased through the Pliocene and into the present. In the western part of the basin, the Kopet-Dag foldbelt was thrust onto the Amu-Darya basin margin, which resulted in formation of a foredeep. However, as most of the compression from the south was accommodated by dextral slip along the frontal Kopet-Dag fault (Ashkhabad fault; Lyberis and Manby, 1999) rather than by thrusting, there was limited thrust loading, resulting in relatively shallow foredeep. Thickness of the orogenic clastic sequence within the foredeep generally does not exceed $2 \mathrm{~km}$.

Protrusion of the Pamir block northward during Miocene to Quaternary time resulted in thrusting and folding of MesozoicPaleogene rocks of the Afghan-Tajik basin (fig. 1). Although thrusting from the east did not extend into the Amu-Darya basin, the compression led to active tectonic movements. East-westtrending faults, mainly with dextral slip, were formed in northern Afghanistan (Brookfield and Hashmat, 2001). The Repetek strike-slip fault (north of the Repetek-Kelif zone in fig. 2), which inherited a Jurassic or older fault zone in the Murgab depression, and faults bordering the Bukhara and Chardzhou structural steps were also formed at this time (Otto, 1997). All local structural uplifts along the eastern and southern basin margins were produced during this stage of tectonic deformation.
The beginning of Alpine deformation in the Amu-Darya basin is marked by a widespread pre-late Oligocene unconformity. Upper Oligocene-lower Miocene deposits are marine to lagoonal, mostly fine grained clastic rocks with beds of gypsum and coquina. Clastic material was derived primarily from platform provenances rather than from orogenic uplifts. Middle Miocene strata and the lower part of the upper Miocene sequence in the Kopet-Dag foredeep and on the slope of the Karakum high consist of marine to lagoonal clastics with beds of limestone. They change eastward into coarser continental facies, grading from lacustrine to eolian deposits derived from the rising mountains to the south and southeast. Upper Miocene-Quaternary strata of the entire basin are composed of lacustrine and alluvial orogenic clastic deposits. Maximum thickness of the synorogenic upper OligoceneQuaternary sequence reaches about $2 \mathrm{~km}$ in the Kopet-Dag foredeep. The sequence is 1 to $1.5 \mathrm{~km}$ thick in the Murgab depression and adjoining areas. East of the Amu-Darya basin, this sequence is as much as 5 to $7 \mathrm{~km}$ thick in synclinoria of the Afghan-Tajik basin.

\section{Present-Day Structure}

In the structure of Jurassic-Tertiary strata, the Amu-Darya basin is a large structural low surrounded by mountain ranges on the south and by highs of the epi-Hercynian basement on the north. The deepest parts of the basin are the Kopet-Dag foredeep and the Murgab depression (fig. 2), where depths to the base of Jurassic rocks reach 6 to $8 \mathrm{~km}$. North of the Kopet-Dag foredeep, the sedimentary strata rise toward the Karakum high, on the crest of which Triassic rocks are absent and the basement is as shallow as $2 \mathrm{~km}$. From this high, the basement descends eastward into the shallower Khiva-Zaunguz depression (fig. 2), where the depth to the base of the Jurassic is $4-5 \mathrm{~km}$. On the basis of seismic data, the depression is underlain by a near north-south-oriented graben, which is filled with more than $3 \mathrm{~km}$ of Triassic rocks (fig. 3).

The northeastern part of the Amu-Darya basin is occupied by two prominent structures, the Bukhara and Chardzhou structural steps bounded by deep faults (fig. 2). Across the steps, the basement was downthrown from the Kyzylkum high into the basin. The Chardzhou step is terminated on the southeast by the Beshkent depression, where the base of the Jurassic is at a depth of more than $5 \mathrm{~km}$.

The northern boundary of the Murgab depression is the Repetek fault, the largest intrabasinal fault of the Amu-Darya basin (fig. 2). The eastern segment of the fault is accompanied by a chain of Upper Jurassic salt domes with amplitudes as high as 1,000 m; this chain constitutes the Repetek-Kelif zone. Westward, the salt thins and pinches out, and salt domes disappear. The Murgab depression contains three relatively uplifted structures - the Mary and Uchadzhi uplifts in Turkmenistan and the Andhoy uplift in Afghanistan. The Andhoy uplift, which contains the major gas fields of Afghanistan, is basically a buried western spur of the North Afghan high. In this report, the North Afghan high, a highland with elevations locally exceeding $2,500 \mathrm{~m}$, is not included in the Amu-Darya basin. Triassic and 
Jurassic rocks are absent on the crest of the high but are present on its slopes. The basement is exposed in the southeastern part of the high and lies beneath Cretaceous-Paleogene rocks at depths of 1,200-1,500 $\mathrm{m}$ in its western part (Bratash and others, 1970). To the north, the basement of the North Afghan high is downthrown into the Afghan-Tajik basin along a fault with a vertical displacement of about $4 \mathrm{~km}$ (Bratash and others, 1970).

South of the Murgab depression is the large Badkhyz-Maimana uplift, which is cut on the east by the northern boundary fault of the Bande Turkestan foldbelt (fig. 2). Lower-Middle Jurassic and partly Upper Jurassic rocks are absent on the uplift. However, in Tertiary time the uplift was involved in active subsidence and subsequently was covered by a thick pile of sediments. The top of pre-Jurassic rocks of the uplift dips to the north to depths of 800 to $3,000 \mathrm{~m}$.

The southernmost structural unit of the Amu-Darya basin is the Kushka zone of folds (fig. 2). This zone, which is the western plunge of the Bande Turkestan foldbelt, is composed chiefly of moderately folded Cretaceous and thick Paleogene rocks. On the north, the zone is separated from the Badkhyz-Maimana uplift by the narrow Kalaimor trough.

The basement of the Amu-Darya basin is characterized by a clearly expressed fault-block structure. In addition to the principal regional faults shown in figure 2 , a large number of other faults have been identified that border the main structural units of the basin and commonly separate them into smaller uplifted and subsided blocks. The faults either extend upward into the sedimentary cover or are expressed there as flexures. The majority of the faults were formed during the Neogene-Quaternary tectonic event; however, some of them are reactivated older basement fractures. For example, the regional fault that crosses the Khiva-Zaunguz depression (fig. 2) is a reactivated fault along the Triassic graben-rift (fig. 3). Pre-Tertiary faults have been identified mostly on the better known Bukhara and Chardzhou steps. These faults generally trend east-west (Tian Shan strike), oblique to the northwest strike of younger faults bounding the steps (Babaev, 1993).

The majority of known local anticlinal structures of the Amu-Darya basin are young, and they were formed during Neogene tectonic deformation. Many of the structures, which have amplitudes that are commonly range from 200 to $400 \mathrm{~m}$, are arranged into linear anticlinal zones along the faults. Little information is available on the presence and abundance of local anticlines formed prior to Neogene deformation. These older anticlines have been identified in some areas, such as on the Bukhara and Chardzhou steps (Babaev, 1993; Ubaykhodzhaev and others, 1984), on the Badkhyz-Maimana uplift (Aynazarov, 1985), and in the Kopet-Dag foredeep and adjacent areas to the east and north (Melikhov and others, 1987). Some of these Jurassic-Cretaceous anticlinal structures experienced continuous uplift in Neogene time, and others were buried under younger rocks. Different local structures are present on the Karakum high and Bakhardok monocline. These are isometric, areally small uplifts, with closures commonly less than $50 \mathrm{~m}$. Apparently, they were present in pre-Neogene time, as many of the structures on the Bakhardok monocline were tilted and opened to the north during formation of the Kopet-Dag foredeep.

\section{Total Petroleum System}

A single total petroleum system (TPS), the Amu-Darya Jurassic-Cretaceous petroleum system, has been identified in the basin. The principal original petroleum reserves of the TPS are gas, estimated to total 230 trillion cubic feet (TCF) (Petroconsultants, 1996). The reserves of hydrocarbon liquids are much smaller; their volume is slightly less than 2 billion barrels (BB), of which about 60 percent is condensate and 40 percent ( 767 million barrels) is oil. The dominance of gas is related to both the character of the source rocks and their high maturity.

Stratigraphically, the Amu-Darya Jurassic-Cretaceous TPS includes the entire sedimentary cover, ranging from Triassic to Cenozoic in age; however, petroleum source rocks and almost all hydrocarbon reserves are in Jurassic-Cretaceous strata. The major part of the reserves is concentrated in two narrow stratigraphic intervals -Oxfordian (Upper Jurassic) carbonates and in Hauterivian (Lower Cretaceous) sandstones that are separated by thick salt deposits of the Upper Jurassic Gaurdak Formation in the central area of the TPS. Other parts of the sedimentary succession are less productive, and their productivity is limited to the marginal areas of the TPS where salt of the Gaurdak Formation is absent.

The TPS contains two principal source-rock intervals: (1) Lower to Middle Jurassic coaly shales and coals with dominantly type-III gas-prone kerogen, and (2) Upper Jurassic deep-water marine black shales with type-II kerogen. Both source rocks are in the gas-generation window over much of the TPS area, and many productive fields probably contain a mix of hydrocarbons derived from both sources. Migration of hydrocarbons into Cretaceous rocks took place on the margins of the Amu-Darya basin where the regional Upper Jurassic salt seal pinches out.

\section{Amu-Darya Jurassic-Cretaceous Total Petroleum System}

\section{Discovery History}

Petroleum exploration in the Amu-Darya basin began before the World War II but was mainly limited to gravimetric and magnetic mapping and drilling of shallow core holes. The work was resumed in the early 1950s, and in 1953 the first relatively small (17 billion cubic feet-BCF) gas discovery in the Setalantepe field was made on the Bukhara step (fig. 2). This discovery gave rise to extensive exploration efforts, including reflection seismic surveys, in various areas of the basin. In 1956, the first giant field, the Gazli gas field, with original reserves of more than $25 \mathrm{TCF}$, was discovered, also on the Bukhara step (fig. 2). During the late 1950s and early 1960s, hydrocarbon fields were discovered in many major structural units of the basin. The chain of large discoveries continued through the 1970s and 1980s, the most significant being the Shatlyk gas field with reserves of more than 33 TCF 
in 1968, the Dauletabad gas field with reserves of about 60 TCF in 1974, and the Kokdumalak gas-oil field with reserves of almost 2 billion barrels of oil equivalent (BBOE) in 1985 (fig. 2). The Khangiran gas field in Iran (12.7 TCF) was discovered in 1968, and the largest (about 2 TCF) gas field of Afghanistan, the Khodzha-Gugerdag field, was discovered in 1961. Discoveries of the last 15 years are mostly comparatively small except for the Yashlar field (fig. 2), for which gas reserves have not been disclosed - these reserves may be as large as 15 to 35 TCF.

\section{Petroleum Occurrence}

The Amu-Darya basin is dominantly gas prone; gas fields are known in all structural units of the basin, whereas only a few relatively small oil fields have been discovered in the very marginal northeastern and southeastern parts of the basin. The Petroconsultants (1996) file lists 250 discovered gas and oil fields in the basin, of which less than half are of commercial value.

Large gas reserves of the Murgab depression and northwest slope of the Badkhyz-Maimana uplift (Dauletabad field) are concentrated in the Hauterivian Shatlyk Bed sandstone. All fields are in structural traps except for the Dauletabad field, the trapping mechanism of which is poorly understood (see below). Subsalt Jurassic rocks of this area have not been explored because of large drilling depths and high reservoir overpressures that hamper drilling through Gaurdak salt. Also, until recently, the seismic resolution below the salt was largely inadequate for reliable mapping of prospects. Subsalt rocks have been penetrated in a few wells, but commercial flows were tested only in the Yashlar field (fig. 2).

The second most important petroleum region of the Amu-Darya basin encompasses the Chardzhou and Bukhara steps and the Beshkent depression (fig. 2). Gaurdak salt covers the Chardzhou step and Beshkent depression, and the principal hydrocarbon reserves there are in Upper Jurassic carbonates below the salt seal. The traps are either Oxfordian reefs or are structural; some are a combination of these two types. On most of the Bukhara step, the salt and reefs are absent, and hydrocarbon accumulations are in structural traps in reservoirs varying in age from Middle Jurassic to Late Cretaceous. In the southeastern area of the step covered by Gaurdak salt, several fields are in Oxfordian reef traps. Potentially commercial tar sands are present in exposures in the northeastern marginal part of the step (Khaimov and others, 1983).

All gas fields of the Khiva-Zaunguz depression, Malay-Bagadzha uplift, and Beurdeshik step are in structural traps (fig. 2). They produce from both Upper Jurassic carbonates and Lower Cretaceous sandstones. A few pools are also known in the Lower-Middle Jurassic clastic rocks. About 20 gas fields have been discovered on the Karakum high; all of them are in areally small, low-amplitude structural traps. The principal reservoirs are Lower and Upper Cretaceous sandstones; a few pools are present in Upper Jurassic carbonates. The fields are largely depleted. Several small gas fields have been found on the Bakhardok monocline in local structural uplifts with amplitudes not exceeding $100 \mathrm{~m}$. The major reservoirs are Upper Jurassic and Neocomian carbonates.

The giant Khangiran gas field (almost $13 \mathrm{TCF}$ ) and two much smaller fields have been found in the Iranian part of the Kopet-Dag foredeep, close to the boundary with the BadkhyzMaimana uplift (fig. 2). The fields are in frontal folds of the Kopet-Dag. In the Khangiran field, the reserves are in Neocomian clastic and Upper Jurassic carbonate reservoirs; other fields produce from Neocomian clastics. In spite of significant exploration efforts, no fields have been found in the rest of the foredeep. The last producing area of the basin is the Kushka fold zone where two relatively small gas fields are present in the Turkmenistan part of the zone. The fields are in structural traps in Lower and Upper Cretaceous and in Paleocene clastic reservoirs. Noncommercial gas shows were obtained in the Afghanistan part of the zone.

\section{Source Rocks}

Few modern geochemical data on oil to source rock correlation are available for the Amu-Darya basin. Most of the liquid hydrocarbons are highly mature condensates containing very small amounts of biomarkers, which do not provide adequate data for such correlation. The composition of biomarkers indicates that many condensate accumulations were generated deep in the thermal gas-window zone and that the source rocks contain terrestrial organic matter (Sokolova and others, 1993). Secondary condensates that are related to dissolution of primary oil pools in gas are interpreted to be present on the Chardzhou step (Maksimov and others, 1987). Oil pools are few, and many of them are actually retrograde condensates (Maksimov and others, 1987). The group composition of oils varies widely; in some fields oils are characterized by a high content of aromatic hydrocarbons, whereas oils in other fields are dominantly composed of paraffinic and naphthenic hydrocarbons (Starobinets, 1974). Most of the oils are isotopically heavy ( -23 to $-27 \%$ ), although some pools of isotopically lighter (about $-30 \%$ ) oils are known on the Bukhara and Chardzhou steps (Akramkhodzhaev and others, 1981; Maksimov and others, 1987). Variations in isotopic composition of oils between pools in different stratigraphic intervals are smaller than those variations between pools in the same stratigraphic interval located in different areas.

Gases of the Amu-Darya basin are isotopically heavy $(-30$ to $-41 \%$ ) and are of typical thermogenic origin (Ovodov and Pechernikov, 1987). Generally, gases in Cretaceous rocks are drier and contain substantially smaller concentrations of ethane and heavier homologs, especially in areas where thick Jurassic salt is present. The gases contain little or no sulfur, which was utilized in reactions with iron oxides as indicated by the widespread presence of pyrite (Semenovich and others, 1983). Gases in Upper Jurassic carbonates contain variable 


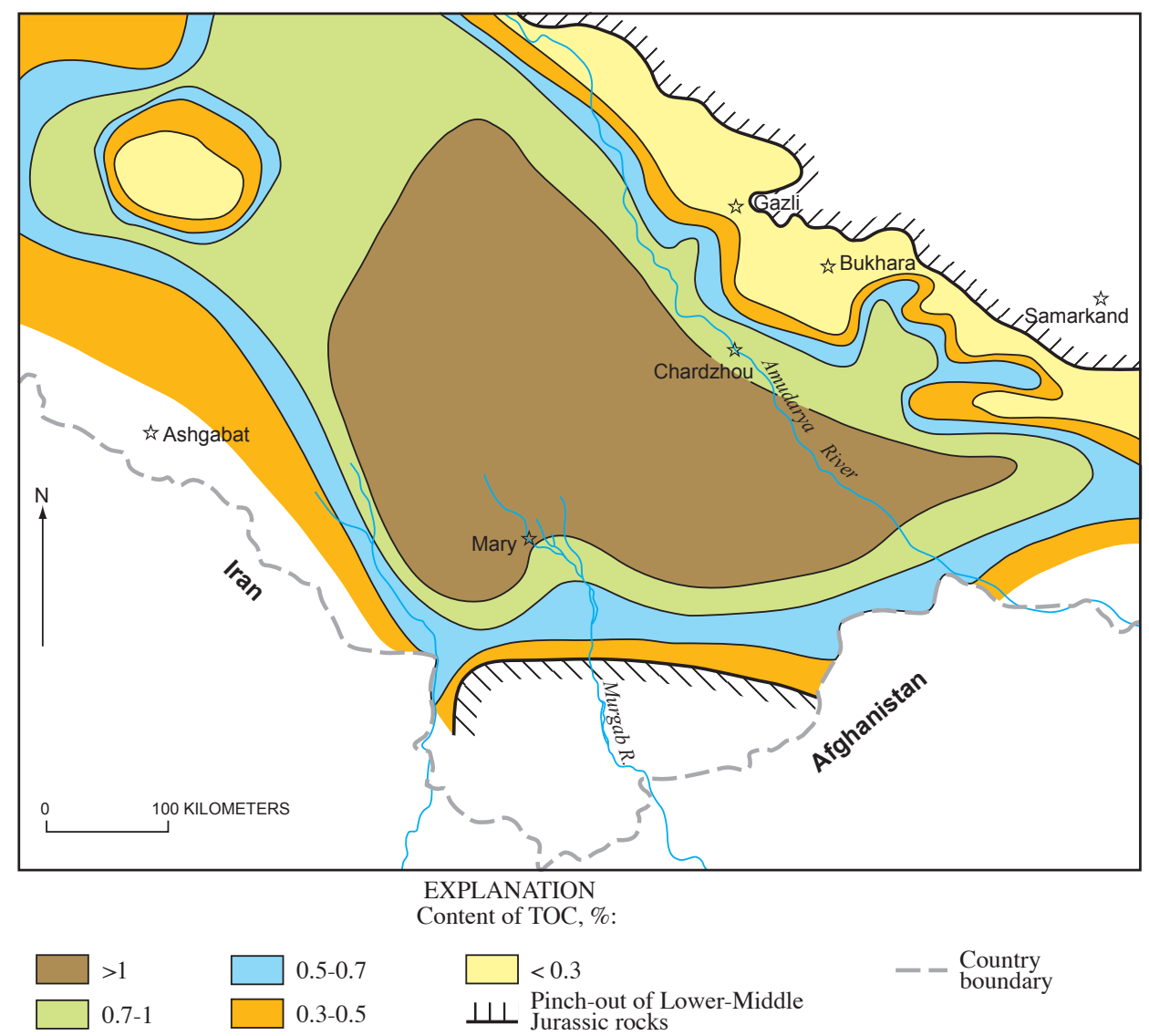

Figure 10. Distribution of average total organic carbon content in LowerMiddle Jurassic rocks of Amu-Darya basin (modified after Polyakova, 1977). Data are mostly available for marginal parts of basin, and model is speculative in its central area.

amounts of condensate and are commonly more sulfurous. The concentration of hydrogen sulfide varies from less than 0.1 percent in fields on the basin margins where the Gaurdak Formation is thin or absent to as much as $4-8$ percent where carbonate reservoirs are overlain by thick anhydrite and salt (Lomako and Khudaynazarov, 1983). In summary, the available geochemical data on both liquid and gaseous hydrocarbons demonstrate high maturity of source rocks but do not indicate specific source-rock formations.

The areal and stratigraphic distribution of gas and oil accumulations and data on organic richness and maturity of rocks indicate that most, if not all, hydrocarbons in the Amu-Darya Jurassic-Cretaceous petroleum system were generated from source rocks in two stratigraphic intervals - Lower to Middle Jurassic coaly clastics and coals and Upper Jurassic (primarily Oxfordian) basinal black shales.

The Lower-Middle Jurassic (more precisely Lower Jurassic-lower Callovian) sequence is thick (fig. 5) and consists primarily of continental clastic rocks, which are coarser on the margins and finer toward the central basin area. Where penetrated by wells, the sequence is commonly observed to contain thin coal beds. Coal beds are thicker at the basin margins and are mined in northern Afghanistan. Marine facies compose the sequence in the Kopet-Dag foldbelt and probably are present in the foredeep at great depths. Although data are scarce, especially in the Murgab depression and adjoining deep areas where well penetrations are few, the average total organic carbon (TOC) in sampled rocks generally exceeds one percent, except on the marginal highs where it is lower (fig. 10). The organic matter is of terrestrial origin with dominant type-III kerogen. The present-day geothermal gradient in the Amu-Darya basin is relatively high; in most areas it ranges from $3.0^{\circ}$ to $3.5^{\circ} \mathrm{C} / 100 \mathrm{~m}$ (Ovodov and Pechernikov, 1987), resulting in high formation temperatures in LowerMiddle Jurassic rocks at depth. Measurements of the vitrinite reflectance values and extrapolation of these measurements to undrilled depths show that, in the central and southern areas of the basin, the Lower-Middle Jurassic sequence is in the wet-gas- to dry-gas-generation windows (Mavyev, 1986). Vitrinite reflectance at the top of the sequence varies from 1.15 percent at a depth of about $3,000 \mathrm{~m}$ to $2.30-2.40$ percent at depths of 4,600-5,500 $\mathrm{m}$ (Kuleshov and Ignatova, 1990). At the bottom of the sequence, the vitrinite reflectance values may be as high as 3.6 percent. The Lower-Middle Jurassic sequence is in the oil window only in the northernmost part of the basin and on the Karakum high. The base of the sequence reached the oil-generation window by Late Cretaceous time or earlier; it reached the gas-generation window in most of the basin during Paleogene time (figs. 11, 12).

The Upper Jurassic source rocks are represented by a basinal black-shale facies contemporaneous to shallow-water limestones and reefs on the periphery of the deep-water basin (fig. 6). Rocks of the basinal facies have been penetrated by wells and studied primarily in the marginal zone of the basin, on the Chardzhou step where they were assigned to Khodzhaipak Formation (Akramkhodzhaev and Egamberdyev, 1985). In 


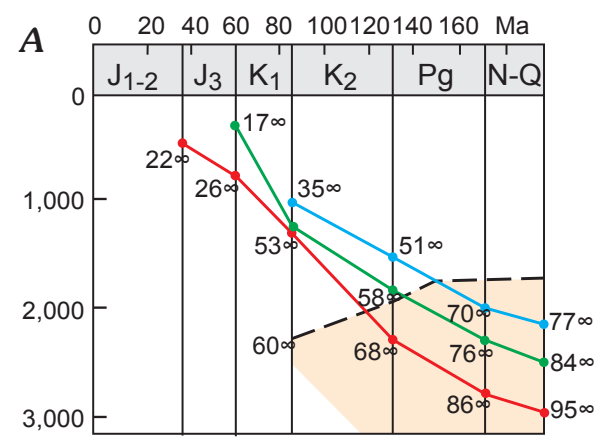

\section{EXPLANATION}

Temperature curves

— Base of Lower-Middle Jurassic

- Base of Upper Jurassic

Base of Lower Cretaceous
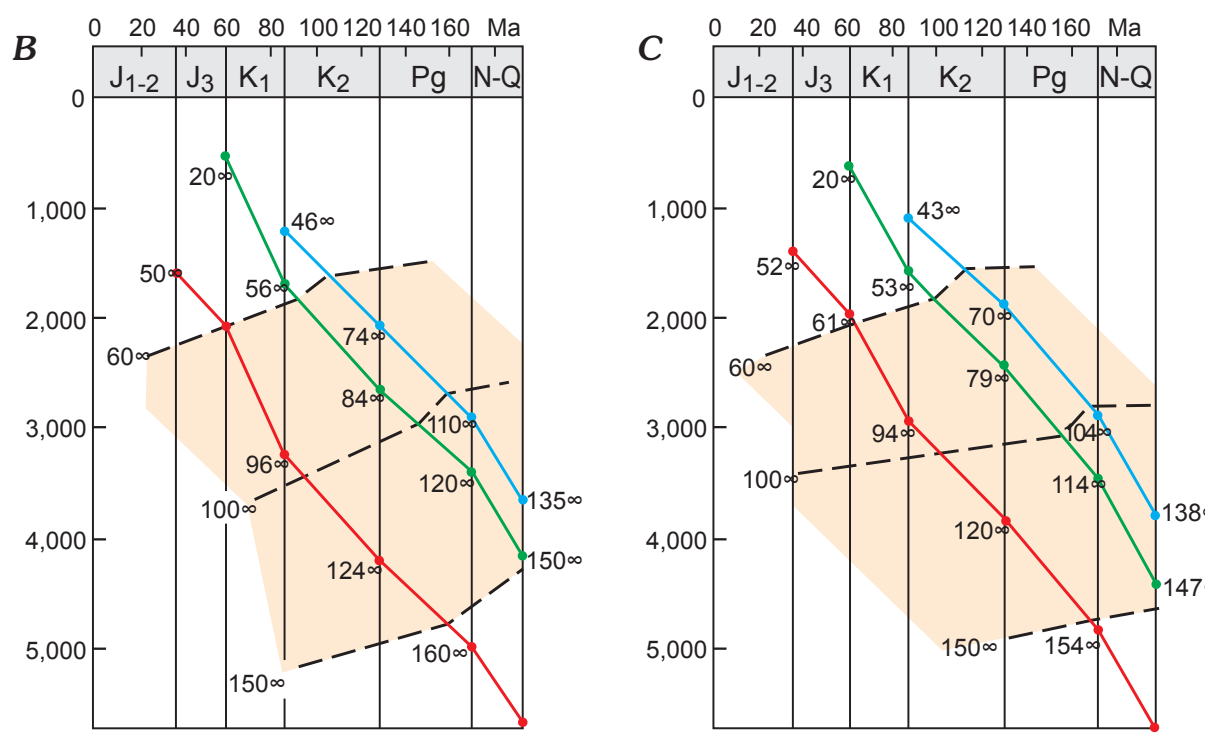

- - - Isotermal line

Figure 11. Maturation models for northern Khiva-Zaunguz depression $(A)$, Murgab depression $(B)$, and Kopet-Dag foredeep $(C)($ modified from Yermolkin, 1986). Temperatures are in degrees Celsius, depths are in meters. Ma, million years; J1-2, Lower-Middle Jurassic; J3, Upper Jurassic; K1, Lower Cretaceous; K2, Upper Cretaceous; Pg, Paleogene; N-0, Neogene-Quaternary.

this area, the formation is 40 to $150 \mathrm{~m}$ thick and includes middle and upper Oxfordian rocks. The thicker lower part of the formation is composed of alternating black, argillaceous, bituminous limestones and marls with gray largely nonbituminous limestones with benthic fossils. Although no data on the total organic carbon (TOC) contents in these rocks are available, lithologic composition and the presence of benthic fossils indicate that they are probably not high. However, black limestones and marls with higher TOC contents are possibly more abundant basinward, where the water depths were greater and more anoxic marine conditions may have existed.

The upper part of the Khodzhaipak Formation, primarily of late Oxfordian age, is known as the radioactive bed, which is 5 to $30 \mathrm{~m}$ thick on the Chardzhou step (fig. 2). Black, thinly laminated calcareous shales and argillaceous limestones that compose the bed commonly contain 2.5 to 5 percent TOC, and in some samples the TOC is as high as 15 percent (Nevmirich and others, 1996; Fortunatova, 1985). Facies characteristics indicate that the kerogen is probably type II. About 10 percent of the organic matter is represented by bitumen, and hydrocarbons constitute 59 to 67 percent of the bitumen (Nevmirich and others, 1996). Source-rock potential of the bed may further improve toward the basin interior.

Source rocks of the radioactive bed are in the gas window and are overmature with respect to oil generation over the entire area of their distribution except on the structurally highest part of the Chardzhou step. The calculated maturity level corresponds to vitrinite reflectance varying from 1.25 to 2.25 percent (Kuleshov and Ignatova, 1990). The rocks reached the oil-generation window in Late Cretaceous to Paleogene time and reached the gas-generation window in the Neogene (figs. 11, 12).
Some investigators (for example, Maksimov and others, 1987; Yermolkin, 1986; Akramkhodzhaev and others, 1981) hypothesize that Lower Cretaceous rocks of the Amu-Darya basin also possess generative potential and that these rocks generated the gas found in Neocomian rocks of the Murgab depression. Their interpretation is based on the presence of large gas fields producing from the Neocomian Shatlyk Bed which, in the Murgab depression, is separated from subsalt Jurassic source rocks by the Gaurdak Formation salt as being an indicator of the indigenous source for this gas. Alternative models assume (1) vertical migration of Jurassic gas into Cretaceous reservoirs outside the pinch-out zone of the salt and subsequent lateral migration and (2) vertical migration through faults that offset the salt. These models satisfactorily explain the presence of large gas fields in the Shatlyk Bed (Krylov, 1979; Ovodov and Pechernikov, 1987; Semashev, 1983); the first of these two models is well founded by data on the Dauletabad field, discussed below.

Lithological and geochemical data contradict the hypothesis of the presence of source rocks in the Lower Cretaceous sequence. Neocomian rocks in the eastern areas of the basin are mainly represented by variegated and red lagoonal to continental facies containing low concentrations of organic matter. In the Kopet Dag foredeep and on adjoining structures, rocks of this age are largely shallow-water marine carbonates with TOC averaging about 0.5 percent and containing mixed types-II and -III kerogen. Over most of this area, Neocomian rocks are in the oil-generation window (Kuleshov and Ignatova, 1990). The dry composition of the gases in this section does not correlate with the composition of kerogen at that level of maturity. Only in the deepest part 
of the foredeep are Neocomian rocks in the gas-window zone and could have generated some gas. Overlying Aptian-Albian rocks are richer in organic matter-the highest TOC content, averaging 0.7 to 0.9 percent, is in the lower Aptian (Krylov, 1979). However, Aptian-Albian rocks have reached moderate maturity only in the deepest areas (fig. 11). Furthermore, dissolved gas in water within these rocks contains mostly nitrogen, which indicates that hydrocarbon generation is absent or minimal. Aptian-Albian and younger rocks do not contain hydrocarbon accumulations in areas where Gaurdak salt is present, which also indicates the absence of indigenous generative potential.

\section{Reservoir Rocks}

Upper Jurassic carbonates and Hauterivian Shatlyk Bed sandstones are the two reservoir sequences that contain most of the hydrocarbon reserves of the Amu-Darya basin. Upper Jurassic carbonates contain the principal gas, gas condensate, and oil reserves in Uzbekistan, most of which are on the Chardzhou and Bukhara steps. The Shatlyk Bed contains more than 90 percent of the gas reserves of Turkmenistan, primarily in the Murgab depression and adjoining areas. Other productive intervals are mainly present on the basin margins and contain much smaller reserves.

The reservoir properties of Upper Jurassic carbonates are closely related to their depositional facies. The best reservoir properties characterize reef-core carbonates in both the barrier reef system and isolated pinnacle reefs (Ibragimov and Ivanov, 1984; Korsun and Kushnerov, 1986). Reef-core carbonates are composed of corals and algae and their detritus. Limestones are commonly fractured, leached, and dolomitized to various degrees (Amanniyazov and Nevmirich, 1985). Porosity of reef carbonates varies from 14 to 19 percent and permeability varies from 25 to 400 millidarcies $(\mathrm{mD})$. Reservoir rocks average 86 percent of the total thickness of the reef sequence and may be as much as $200 \mathrm{~m}$ thick (Ilyin and Fortunatova, 1988). The shallow-shelf back-reef facies is composed of various bioclastic and oolitic limestones and limestone breccia. Porosities are relatively high, especially in oolitic varieties where they range from 10 to 18 percent, and permeability is commonly 10 to $40 \mathrm{mD}$. However, the thickness of porous and permeable rocks is substantially less than in reef-core facies and commonly does not exceed several tens of meters. In the basinal area (see fig. 6), reservoir rocks are present only in the lower (upper Callovian-lower Oxfordian) part of the carbonate sequence; the rest of the sequence is composed of deep-water carbonates and marls devoid of reservoir quality. Porosity of reservoir beds ranges from 5.5 to 11 percent, and permeability varies from 0.2 to $10 \mathrm{mD}$ (Ibragimov and Ivanov, 1984). The combined thickness of reservoir beds of the carbonate sequence is commonly only 10 to $40 \mathrm{~m}$. In some areas, reservoir rocks are almost totally absent (Nevmirich and others, 1996). Over most of the Amu-Darya basin, the top of the carbonate sequence lies at depths between 3,000 and 5,000 m. There is no correlation between porosity of the carbonate rocks and their depth (Mavyev, 1986).

The Hauterivian Shatlyk Bed consists of sandstones with lenses and layers of siltstone and claystone. Carbonate beds are present in the Kopet Dag foredeep and Khiva-Zaunguz depression (fig. 2). In the eastern part of the basin, clastic rocks of the Shatlyk Bed grade into salt mixed with clastic material (fig. 13). The sandstones are brown, red, and, in places, variegated, fine to medium grained, and medium sorted. The cement is mostly argillaceous; anhydrite, quartzose, and carbonate cements are present in separate beds on the basin margins, for example, in the Dauletabad (Mavyev, 1986) and Malay (Kryuchkov, 1996) fields (fig. 2). The cement content varies widely, which results in the alternation of densely cemented, low-permeability beds and friable, high-porosity sandstones where the amount of cement is less than 5 percent (Mavyev, 1986; Orazov and others, 1985). The best reservoir rocks are commonly concentrated in the upper part of the Shatlyk Bed. The mineralogical composition of Shatlyk

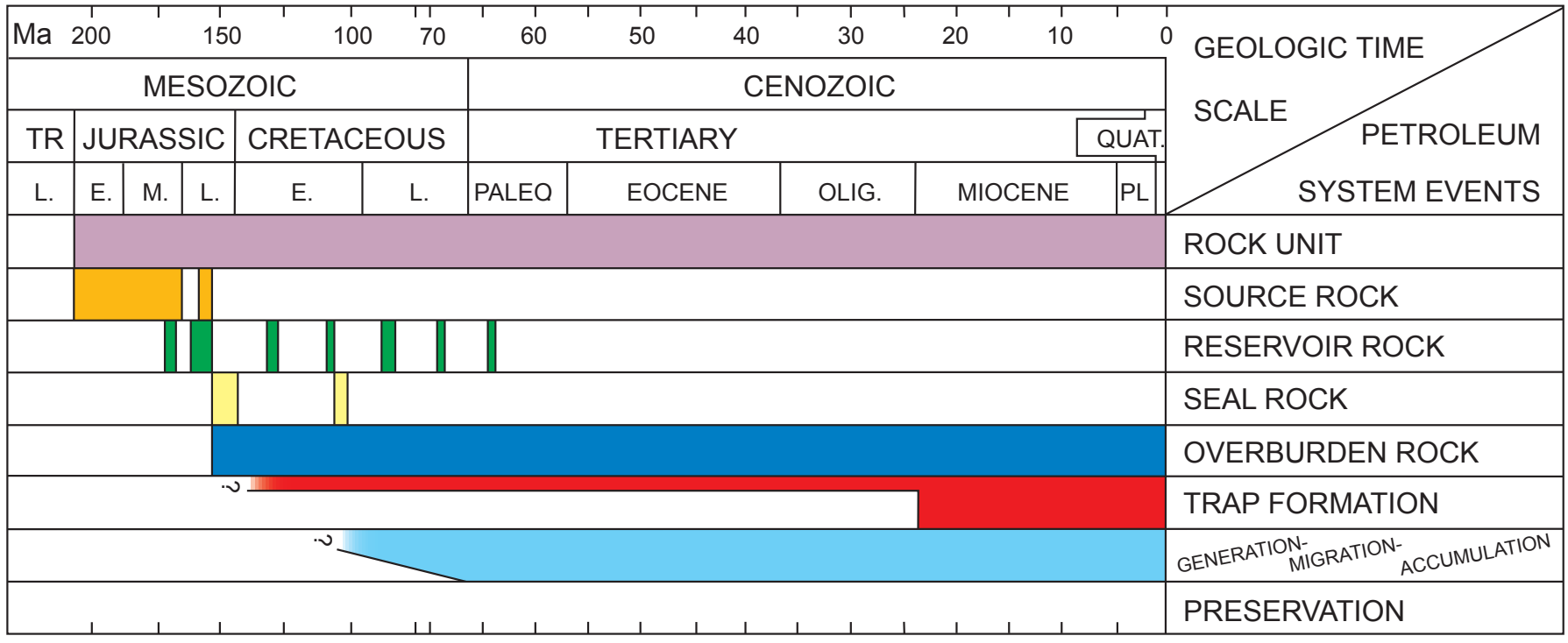

Figure 12. Amu-Darya Jurassic-Cretaceous total petroleum system event chart. Queries indicate uncertainties in extent of events. 
Bed sandstones is dominated by quartz and feldspar; rock fragments are commonly a minor constituent (Amanov, 1991). The proportion of quartz grains generally increases toward the Kopet Dag foredeep (Nedirov, 1992). Porosity of sandstones varies from several percent in densely cemented varieties to $25-33$ percent in friable sandstones. Permeability of the latter commonly exceeds $1,000 \mathrm{mD}$. Original flows from wells are as high as 20 to 35 million cubic feet per day. Thickness of the Shatlyk Bed ranges from zero near the pinch-out zone to $120-130 \mathrm{~m}$ in the central part of the basin (fig. 13). In most of the area, the Shatlyk Bed is at depths of 3 to $3.5 \mathrm{~km}$.

Reservoir rocks in other stratigraphic units of the Amu-Darya basin are chiefly present on the basin margins and, in each unit, they are distributed locally and are productive in one or a few neighboring fields (Tashliev and Znamenskaya, 1991). LowerMiddle Jurassic rocks contain one or two productive sandstone beds in the upper part of the sequence in several fields. The sandstones, which are laterally discontinuous, are commonly poorly sorted and poorly rounded. They consist of quartz and rock fragments with kaolinite, carbonate, and quartz cement (Amanov, 1991). The best reservoir properties of the sandstones are recorded in the northern Khiva-Zaunguz depression, where the top of the section is at depths of about $2 \mathrm{~km}$. Porosity in some samples is as high as 17.4 percent and permeability reaches $40 \mathrm{mD}$ (Maksimov and others, 1986). With increasing depth, reservoir quality diminishes at a high rate due to compaction and diagenesis (Amanov, 1991); at depths of 2.5 to $3 \mathrm{~km}$, porosities are commonly less than 10 percent.

Locally, clastic and some carbonate reservoir rocks are productive throughout the Cretaceous sequence, from the Valanginian through the Maastrichtian (Tashliev and Znamenskaya, 1991; Maksimov and others, 1986). All these productive reservoirs are at shallow to moderate depths, and reservoir properties are relatively good. For example, 10 pay zones are present in Upper Cretaceous rocks of the giant Gazli gas field (figs. 2, 14) at depths of 50 to $1,200 \mathrm{~m}$. Porosity of sandstones at these depths varies from 13 to 23 percent and permeability is measured in hundreds of millidarcies. However, the combined hydrocarbon reserves of all these reservoirs are only several percent of the basin's reserves, and none of the reservoirs (except for a few small pools in the suprasalt TithonianValanginian section) is productive in the central basin areas where the Upper Jurassic salt is present.

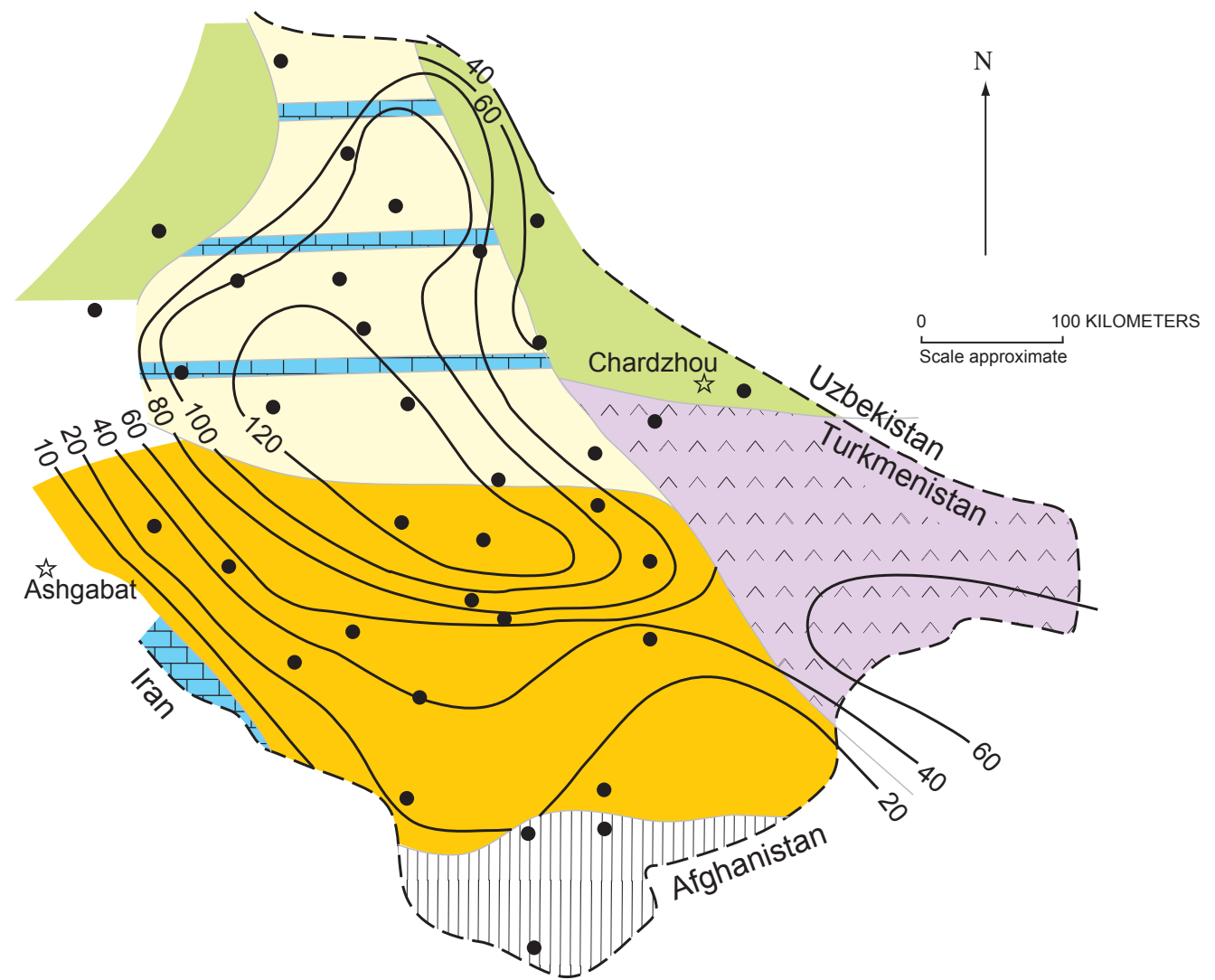

EXPLANATION
Figure 13. Isopach and lithofacies map of Shatlyk Bed and its stratigraphic equivalents in Turkmenistan (modified after Pashaev and others, 1993)

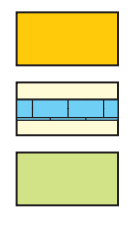

Mainly sandstones

Sandstones with limestone beds

Siltstones and shales

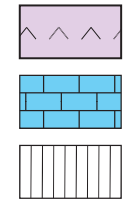

Salt

Mainly limestones

Rocks absent $\begin{array}{cl}\bullet & \text { Wells } \\ -20- & \text { Isopach, m } \\ --- & \text { Country boundary }\end{array}$ 


\section{Traps}

A variety of trap types - structural, stratigraphic, paleogeomorphic (isolated reef buildups), combination of structural and paleogeomorphic, fault-sealed, stratigraphic, and hydrodynamic - are known in the Amu-Darya basin. The majority of discovered fields are in structural and combination structural and paleogeomorphic traps.

The largest structural traps of the basin are on elongate arches typically located along fault zones, although the anticlines themselves are commonly not faulted. Large structural traps, such as that in which the giant Gazli gas field is located (figs. 2, 14), are also present on fault-bounded uplifts of the Bukhara and Chardzhou steps. Outside the arches, structural traps are much smaller, both in area and amplitude. Almost all known structural and combination traps were formed during Neogene-Quaternary tectonic deformation (Gabrielyants and others, 1991) (fig. 12). In the better studied eastern part of the basin, primarily on the Bukhara and Chardzhou steps, there are indications that some structural traps began to form in the Cretaceous and possibly even earlier (Heafford and Lichtman, 1993; Babaev, 1993).
These traps tend to contain greater amounts of gas condensate and oil legs (Babaev, 1993). Some anticlinal uplifts on the Badkhyz-Maimana uplift (fig. 2) also display an increase of amplitude with depth, which may indicate that they began to form as early as Cretaceous time (Aynazarov, 1985). However, the principal part of volume of these traps also was formed during Neogene-Quaternary time. The presence of buried older structures that did not experience structural growth in the Neogene may be inferred from regional tectonic considerations (Otto, 1997); however, only a few such structures have been identified in Jurassic and Lower Cretaceous rocks of the Kopet-Dag foredeep (Melikhov and others, 1987). Many buried structures related to Triassic and Early Jurassic rifting events may be present in Lower-Middle Jurassic rocks, but these rocks generally are at great depths and have not been mapped in detail.

Combination traps contain substantial hydrocarbon reserves in Upper Jurassic carbonates on the Bukhara and Chardzhou steps. The traps are in barrier-reef carbonates intersected by local tectonic structures. Sealing of pools basinward is provided by a transition from porous reef limestones and dolomites to impermeable basinal argillaceous limestones and marls. Local
Figure 14. Cross section through Gazli gas field, Amu-Darya basin (modified after Barikov, 1979). Exact horizontal scale is not available. Approximate length of section is $20-25 \mathrm{~km}$.
S

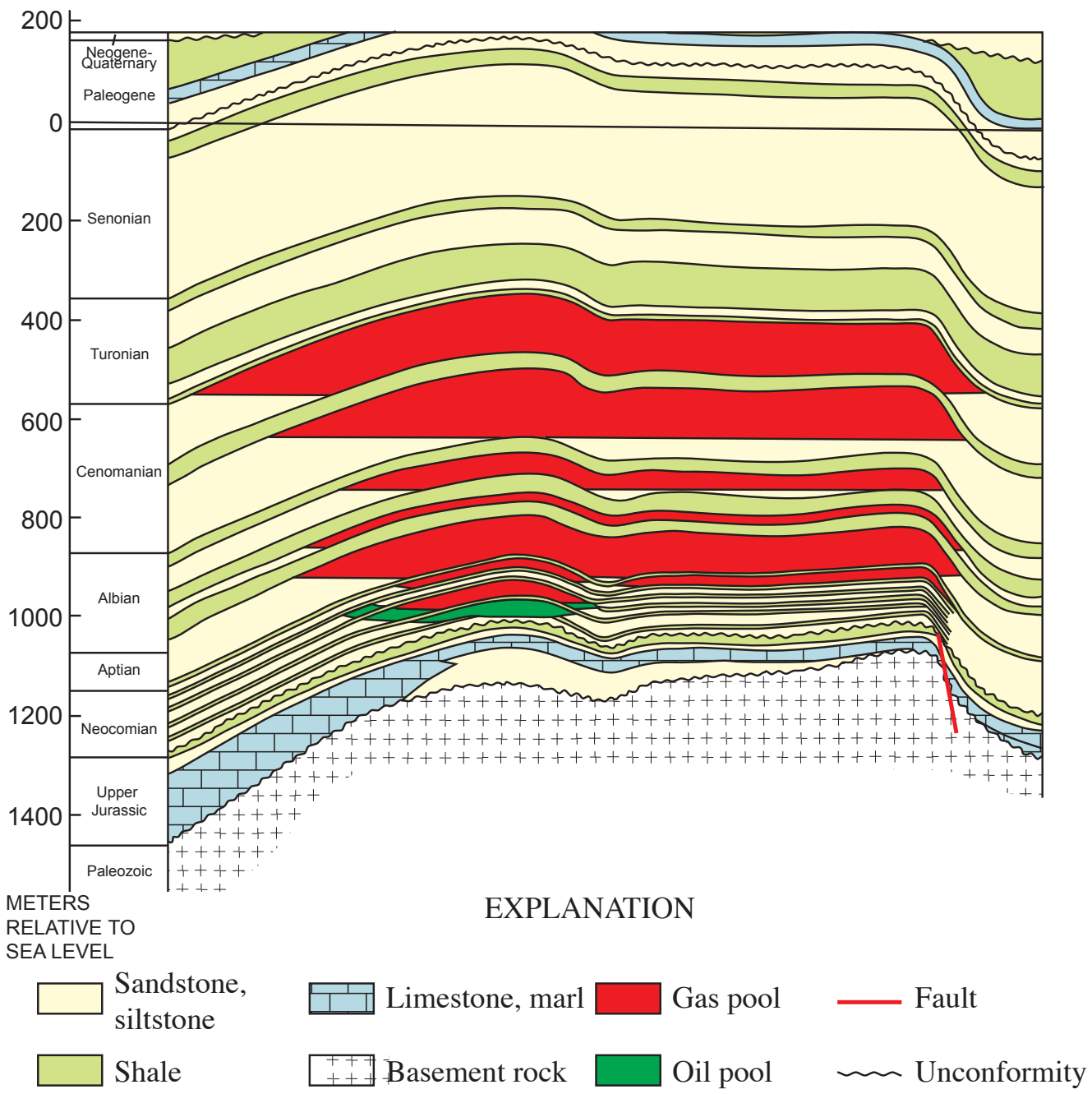




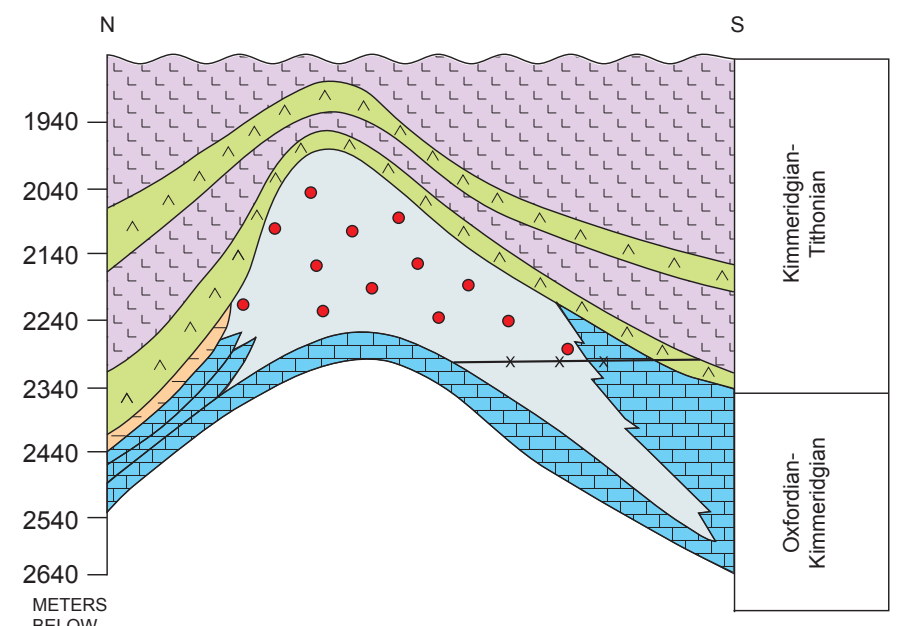

SEA LEVEL

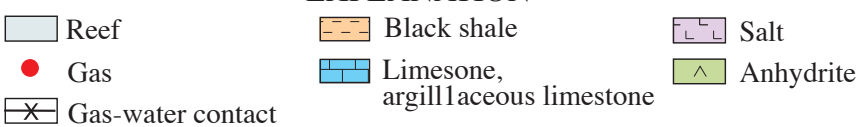

Figure 15. Cross section through Urtabulak gas field, Amu-Darya basin (modified after Dikenshteyn and others, 1983). Horizontal scale is not available. Length of cross section is several kilometers. For location of field see figure 2.

structures provide trapping toward back-reef facies. The large Urtabulak field is an example of a combination trap (figs. 2, 15). Some pools in traps of this type are partly sealed laterally by evaporites that filled tidal channels cutting the barrier reef (Goryunov and Iliyn, 1994).

Several hydrocarbon fields of the Amu-Darya basin are in paleogeomorphic traps. These traps are isolated pinnacles and atolls in Oxfordian carbonates sealed on all sides by Gaurdak Formation salt and by the transition of reef carbonates into impermeable basinal facies. All discovered hydrocarbon fields in isolated reef buildups are on the Chardzhou step; however, traps of this type are considered an important exploration objective in other parts of the basin, especially on its southern margin. The largest field in a reef buildup is the giant Kokdumalak gas condensate and oil field (fig. 2). Areally, the trap is relatively small, but excellent reservoir properties of reef-core carbonates and a large hydrocarbon column result in reserves of about 2 billion barrels of oil equivalent (BBOE).

Only one field in a fault-sealed trap has been discovered in the basin. The field is in Upper Jurassic carbonates in a structural nose cut by a fault that bounds the Chardzhou step on the southwest. More fields of this type are expected along this and other faults (Maksimov and others, 1986).

Many stratigraphic traps in various parts of the sedimentary sequence may be expected in the marginal areas of the AmuDarya basin; however, few wells have yet been drilled to test stratigraphic prospects. Of wells that have been drilled, some tested gas flows, but no significant discoveries have been made. Probably the best defined stratigraphic prospects are on the Bakhardok monocline and Beurdeshik step, in the northwestern part of the basin (fig. 2), where the Upper Jurassic carbonate reservoir is truncated updip by the pre-Cretaceous unconformity and is overlain by Valanginian shale (Melikhov and others, 1988; Maksimov and others, 1986). Stratigraphic traps are expected to be found in a transition zone where Shatlyk Bed sandstones grade updip into contemporaneous salt (Pashaev and others, 1993) (fig. 13). In the Chartak gas field, located near the Malay field (fig. 2), for example, a gas pool in a combination structural and stratigraphic trap is partly sealed by this transition from sandstone to salt (Kryuchkov, 1996). Potential stratigraphic traps may also be present in regional pinch-out zones along marginal basin uplifts, such as the Badkhyz-Maimana uplift and Bukhara step (fig. 2). Another potential zone for exploration for stratigraphic traps is present in the eastern part of the Bakhardok monocline, where Upper Jurassic shallow-shelf reservoir carbonates grade updip into deep-water impermeable facies (Melikhov and others, 1987).

The giant (about $60 \mathrm{TCF}$ ) Dauletabad (Dauletabad-Donmez) gas field on the northern slope of the Badkhyz-Maimana uplift (fig. 2) is in a unique combination stratigraphic, structural, and hydrodynamic trap, in which the hydrodynamic component plays a leading role (fig. 16). The principal gas producer in the field is the lower Hauterivian Shatlyk Bed, which is sealed by upper Hauterivian and Barremian shales and argillaceous carbonates. In various parts of the field, gas also has been tested in wells penetrating other locally developed Neocomian sandstones mainly in stratigraphic traps, but these traps have not been adequately explored (Melikhov and others, 1990). Stratigraphic traps are also expected in Upper Jurassic carbonates in the southernmost part of the field and also farther south where the carbonates are truncated by the pre-Cretaceous unconformity. However, the total potential resources of all these traps (assessed at a maximum of 4 TCF [Melikhov and others, 1990]) are small compared with reserves in the Shatlyk Bed.

The Dauletabad field consists of two productive blocks separated by a graben, in which Shatlyk sandstones are structurally lower and water bearing. The southern block is on the Dauletabad structural nose that opens to the southeast and dips northwest toward the Kopet-Dag foredeep (fig. 16). The northern productive block is on the Donmez monocline, dipping to the north and northwest. Vertical displacements on the bounding faults of the graben increase westward, along its strike, from a few to several tens of meters. More details on the structure and stratigraphy of the field are in Clarke and Kleshchev (1992).

The Shatlyk Bed is composed of reddish-brown sandstones with average porosity of 18 to 20 percent and permeability from several hundred to $1,800 \mathrm{mD}$. Original flows of gas from wells were 20 to 70 million cubic feet per day, and unrestricted flows were as high as 220 million cubic feet per day (Amursky and others, 1984). High-porosity sandstones contain beds and lenses of dense, low-permeability, fine-grained sandstone, siltstone, and claystone. Thickness of the Shatlyk Bed varies from about $40 \mathrm{~m}$ in the northern part of the Dauletabad field to 6-8 m near the southern gas-water contact. Net pay thickness varies from 4 to $24 \mathrm{~m}$, decreasing southward (Smirnov and others, 1980). Combined thickness of low-permeability beds ranges from zero to a maximum of about $16 \mathrm{~m}$ in the northern 
area; these beds may contain an additional 6 percent of the field's gas reserves (Zykin and others, 1992).

Gas produced in the field is 92-95 percent methane, 1.3-1.7 percent heavier homologs, as much as 7 percent nitrogen, and from zero to 3.8 percent carbon dioxide (Semenovich and others, 1983). Hydrogen sulfide, at the maximum measured concentration of 0.948 percent, is present only in the eastern part of the northern block of the field (fig. 16). The gas contains 1.3 barrels of condensate per million cubic feet of gas in the northern block and 3.5 barrels per million cubic feet in the southern block. The isotopic composition of methane ( -32.8 to $-31.7 \%$ ) indicates a typical thermogenic origin (Gavrilov and others, 1985).

The trapping mechanism of the Dauletabad field is complex. In the northwest, the gas-water contact (GWC) follows structural contours, and the trapping mechanism is essentially structural (fig. 16). Slight deviation of the gas-water contact (GWC) from contour lines in the extreme west is probably explained by either imprecise mapping or facies change toward the Kopet-Dag foredeep where Hauterivian sandstones are locally tightly cemented with anhydrite and calcite (Nedirov, 1992). To the south, the trapping is essentially stratigraphic, with Lower Cretaceous rocks truncating Jurassic strata and onlapping progressively older Upper Jurassic rocks (Amursky and others, 1984). Just south of the area shown in figure 16, for example, thin Hauterivian rocks directly overlie Callovian limestones (Khudaykuliev and others, 1989). In the pinch-out zone, Hauterivian (including Shatlyk Bed) sandstones grade into shales (fig. 16). Wells that were drilled into thin $(6-10 \mathrm{~m})$ Shatlyk sandstones between the shale-out zone and the GWC tested water that is structurally updip from the gas pool (Melikhov and others, 1990).
A striking feature of the Dauletabad field is the apparent absence of a permeability barrier along the field's eastern boundary. The GWC obliquely crosses a structural monocline and dips northwestward about 1,000 $\mathrm{m}$ with an average inclination of $18 \mathrm{~m} / \mathrm{km}$ (fig. 16). Many investigators inferred the presence of a fault that defines the eastern boundary of the field (for example, Pankina and others, 1986; Semenovich and others, 1983; Maksimov and others, 1986; Semashev, 1983); however, no fault has been detected by drilling and seismic surveys (Melikhov and others, 1990). Also, there is no apparent stratigraphic barrier along the eastern boundary of the field, where Shatlyk sandstones that extend east of the field boundary were tested and produced water.

The TOC content in Valanginian and Hauterivian rocks of the Dauletabad field varies from 0.03 to 0.24 percent; therefore, these rocks are not a source for the giant gas reserves (Viktorova and others, 1988). One, probably principal, source of gas for the Dauletabad field is clearly indicated by the distribution of hydrogen sulfide (fig. 16), the concentration of which in gas decreases from nearly 1 percent in the southeastern corner of the field to trace amounts in the central part of the northern productive block. In the southern block, hydrogen sulfide has not been detected. In the area where hydrogen sulfide is present in gas, sandstones of the Shatlyk Bed are gray colored and contain pyrite that formed due to reduction of iron in the cement (Pankina and others, 1986), whereas outside this area, Shatlyk sandstones preserve their reddish-brown color. Hydrogen sulfide dissolved in water has been detected in the Shatlyk Bed east of the GWC (Semenovich and others, 1983). Hydrogen sulfide is common in Upper Jurassic reservoirs, including those on the adjacent Bakhardok monocline (Atakhanov, 1988), but it is regionally absent in Cretaceous fields that are separated from Upper

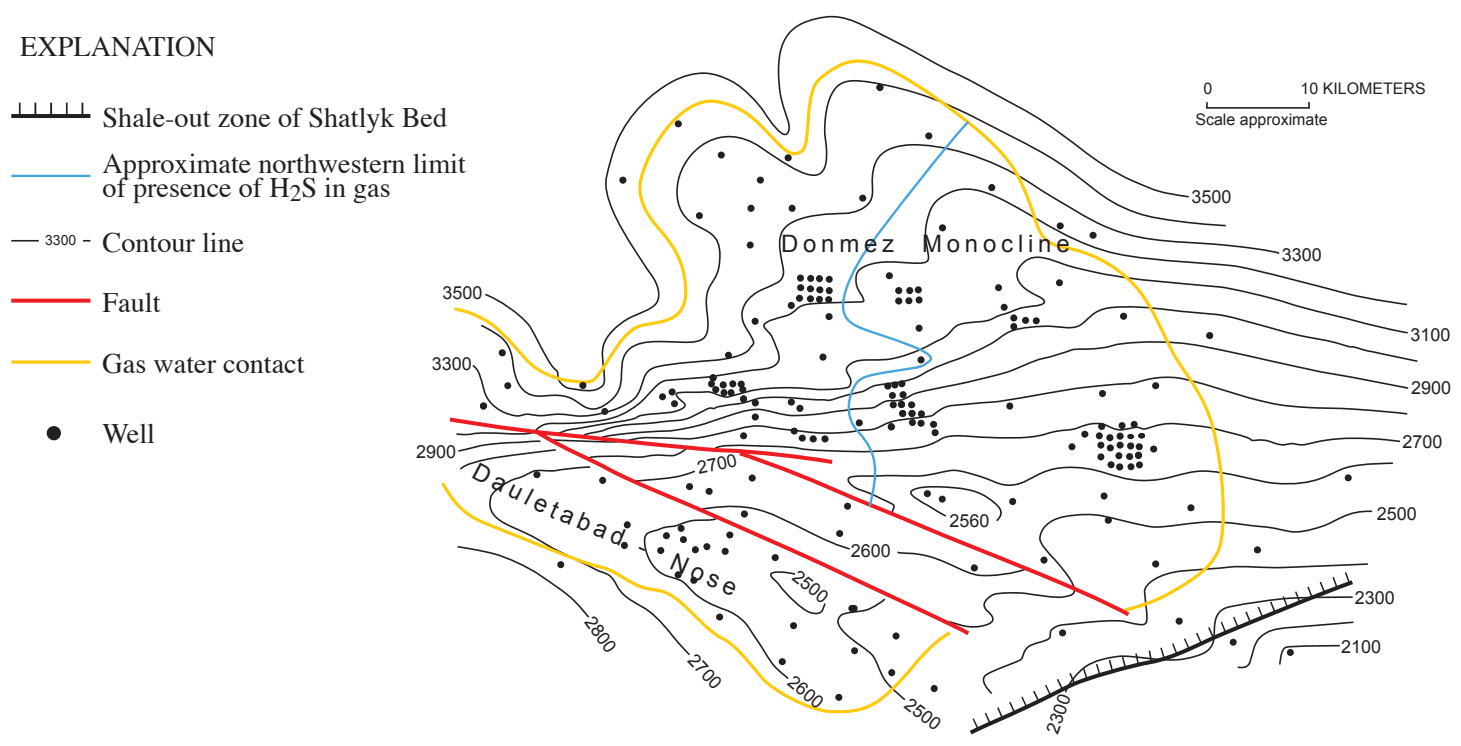

Figure 16. Structural map of Dauletabad gas field, Amu-Darya basin (modified from Melikhov and others, 1990). Contours on top of productive Shaltyk Bed, in meters below sea level. Contour interval 100 meters. Only selected wells are shown; total number of drilled wells exceeds 300 . 
Jurassic rocks by the evaporite seal. Geologic and isotopic data indicate that the sources of hydrogen sulfide in the Dauletabad field are sulfates of the Upper Jurassic Gaurdak Formation (Semenovich and others, 1983; Pankina and others, 1986; Gavrilov and others, 1985). The vertical migration of Jurassic gas into the Shatlyk reservoir took place in the southeastern part of the field where both Gaurdak Formation evaporites and Valanginian shales pinch out and Hauterivian rocks directly overlie the Jurassic. The gas migrated to the pinchout zone from deep areas of the Murgab depression to the north where reduction of sulfates occurred.
Further downdip, migration of gas northward is related to hydrogeologic conditions in the Shatlyk Bed. Subsalt Upper Jurassic rocks of the Murgab depression and adjacent structures are characterized by ubiquitous, abnormally high reservoir pressures, whereas reservoir pressures in suprasalt rocks are hydrostatic. In the zone of hydrodynamic connectivity of Upper Jurassic and Hauterivian rocks in the southeastern part of the Dauletabad field, reservoir pressure in the Shatlyk reservoir exceeds the hydrostatic pressure by 1.3 times, whereas at the northern and northwestern GWC the reservoir pressure is nearly normal hydrostatic (Alekhin, 1984). The

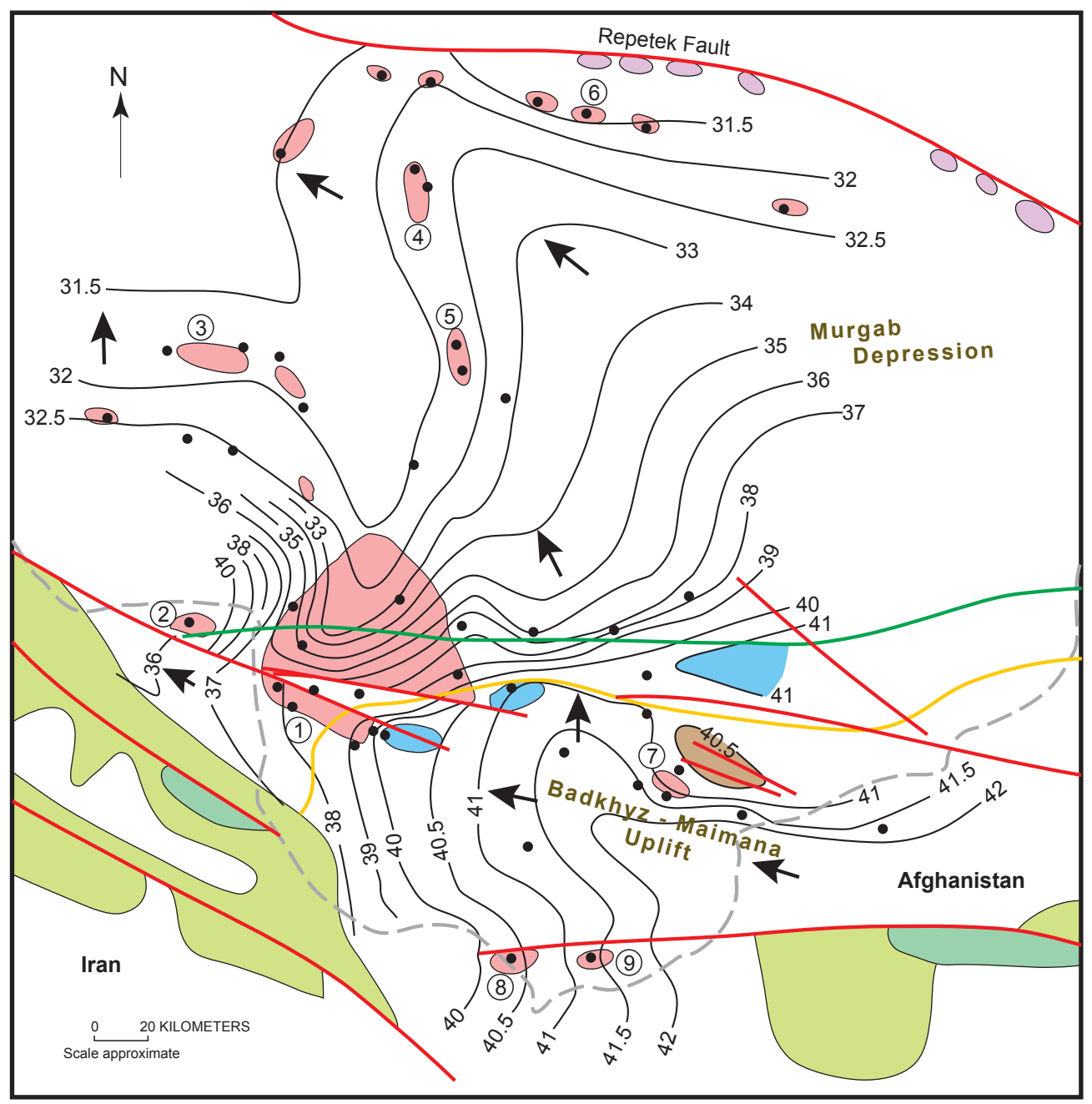

EXPLANATION

Figure 17. Potentiometric map for Shaltyk Bed of Murgab depression and Badkhyz-Maimana uplift (modified from Semashev, 1983). Gas fields in Shaltyk Bed reservoirs are shown. Numbers in circles indicate fields: 1, Dauletabad; 2, Khangiran; 3, Shaltyk; 4, Bayram-Ali; 5, May; 6, Uchadzhi; 7, Karabil; 8, Islim; 9, Karachop.

Outcrop of Triassic-Paleozoic rocks

Outcrop of Jurassic-Cretaceous rocks

Zone of discharge of Shaltyk aquifer

Zone of hydrodynamic connectivity of Shaltyk Bed and Jurassic rocks

Gas field in Shaltyk reservoir

Salt dome
- 40 - Equipotential line, MPa

Fault

_ Pinch-out of Gaurdak Formation Pinch-out of Valanginian and basal Hauterivian shales

$\longleftarrow$ Direction of water flow

- - Country boundary

- Data points 
Shatlyk aquifer is charged in the mountains south of the Dauletabad field. The resulting hydrostatic pressure in the aquifer together with abnormally high reservoir pressure in Jurassic rocks in the zone of hydrodynamic connectivity creates a complex pattern of water movement. South of the regional fault crossing the Dauletabad field, water in the Shatlyk aquifer moves west-northwest, downdip along the Dauletabad structural nose (fig. 16), whereas north of this fault the water flow is directed north and northwest (fig. 17). This pattern of water movement forms a large potentiometric minimum in the Dauletabad field area that assists in downdip movement of gas across the Donmez monocline (fig. 16) and formation of a hydrodynamic trap. The gas probably passes a structural low north of the monocline and migrates updip farther north due to buoyancy, charging structural traps on its route (Semashev, 1983). Factors that control the precise present-day location of the eastern GWC are not clear; however, in the presence of an appreciable potentiometric gradient even a slight decrease in permeability would be sufficient to seal the pool.

The southern productive block of the Dauletabad field probably had a different source for gas that was located in the Kopet-Dag foredeep (Gavrilov and others, 1985; Golovanova, 1995). Gas in the southern block does not contain sulfur,

Table 1. Amu-Darya basin, province 1154, assessment results summary-Allocated resources.

[MMBO, million barrels of oil. BCFG, billion cubic feet of gas. MMBNGL, million barrels of natural gas liquids. MFS, minimum field size assessed (MMBO or BCFG). Prob., probability (including both geologic and accessibility probabilities) of at least one field equal to or greater than the MFS. Results shown are fully risked estimates. For gas fields, all liquids are included under the NGL (natural gas liquids) category. F95 represents a 95-percent chance of at least the amount tabulated. Other fractiles are defined similarly. Fractiles are additive under the assumption of perfect positive correlation. Shading indicates not applicable]

\begin{tabular}{|c|c|c|c|c|c|c|c|c|c|c|c|c|c|c|}
\hline \multirow{2}{*}{$\begin{array}{c}\text { Code } \\
\text { and field } \\
\text { type }\end{array}$} & \multirow[b]{2}{*}{ MFS } & \multirow{2}{*}{$\begin{array}{l}\text { Prob. } \\
(0-1)\end{array}$} & \multicolumn{12}{|c|}{ Undiscovered resources } \\
\hline & & & \multicolumn{4}{|c|}{ Oil (MMBO) } & \multicolumn{4}{|c|}{ Gas (BCFG) } & \multicolumn{4}{|c|}{ NGL (MMBNGL) } \\
\hline Gas fields & & 1.00 & & & & & 46,336 & 150,584 & 317,319 & 162,068 & 1,023 & 3,508 & 8,127 & 3,901 \\
\hline Tota & & 1.00 & 93 & 253 & 507 & 270 & 46,835 & 152,010 & 320,518 & 163,650 & 1,050 & 3,591 & 8,329 & 3,995 \\
\hline
\end{tabular}

1154 Total: Assessed offshore portions of Amu-Darya Basin Province

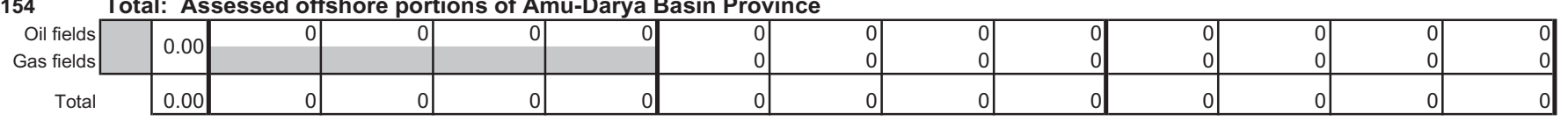

1154 Grand total: Assessed portions of Amu-Darya Basin Province

\begin{tabular}{|c|c|c|c|c|c|c|c|c|c|c|c|c|c|}
\hline Oil fields & 100 & 93 & 253 & 507 & 270 & 499 & 1,426 & 3,198 & 1,582 & 27 & 84 & 202 & \\
\hline Gas fields & & & & & & 46,336 & 150,584 & 317,319 & 162,068 & 1,023 & 3,508 & 8,127 & 3,901 \\
\hline Total & 1.00 & 93 & 253 & 507 & 270 & 46,835 & 152,010 & 320,518 & 163,650 & 1,050 & 3,591 & 8,329 & 3,995 \\
\hline
\end{tabular}

115401 Amu-Darya Jurassic-Cretaceous Total Petroleum System

11540101 Northern and Western Areas Assessment Unit (100\% of undiscovered oil fields and $100 \%$ of undiscovered gas fields allocated to ONSHORE province 1154)

\begin{tabular}{|c|c|c|c|c|c|c|c|c|c|c|c|c|c|c|}
\hline Oil fields & 3 & 100 & 22 & 67 & 129 & 70 & 83 & 259 & 551 & 280 & 5 & 15 & 35 & 17 \\
\hline Gas fields & 18 & 1.00 & & & & & 3,727 & 8,873 & 15,882 & 9,267 & 53 & 134 & 270 & 144 \\
\hline Total & & 1.00 & 22 & 67 & 129 & 70 & 3,810 & 9,132 & 16,433 & 9,547 & 58 & 149 & 305 & 161 \\
\hline
\end{tabular}

11540102 Karabil-Badkhyz Assessment Unit (100\% of undiscovered oil fields and $100 \%$ of undiscovered gas fields allocated to ONSHORE province 1154 )

\begin{tabular}{|c|c|c|c|c|c|c|c|c|c|c|c|c|c|c|}
\hline Oil fields & 3 & 1.00 & 31 & 83 & 161 & 88 & 57 & 160 & 343 & 175 & 3 & 9 & 21 & $\begin{array}{r}10 \\
116\end{array}$ \\
\hline Gas fields & 18 & & & & & & 3,472 & 7,145 & 12,534 & 7,482 & 49 & 108 & 214 & 116 \\
\hline Total & & 1.00 & 31 & 83 & 161 & 88 & 3,529 & 7,305 & 12,877 & 7,657 & 52 & 118 & 235 & 127 \\
\hline
\end{tabular}

11540103 Murgab Depression Suprasalt Assessment Unit (100\% of undiscovered oil fields and $100 \%$ of undiscovered gas fields allocated to ONSHORE province 1154)

\begin{tabular}{|c|c|c|c|c|c|c|c|c|c|c|c|c|c|c|}
\hline $\begin{array}{r}\text { Oil fields } \\
\text { Gas fields }\end{array}$ & \begin{tabular}{r|}
3 \\
18 \\
\end{tabular} & 1.00 & 0 & 0 & 0 & 0 & \begin{tabular}{r|}
0 \\
1,232 \\
\end{tabular} & \begin{tabular}{r|}
0 \\
4,211 \\
\end{tabular} & \begin{tabular}{r|}
0 \\
9,670 \\
\end{tabular} & $\begin{array}{r}0 \\
4,684 \\
\end{array}$ & \begin{tabular}{l|}
0 \\
8 \\
\end{tabular} & \begin{tabular}{r|}
0 \\
29 \\
\end{tabular} & $\begin{array}{r}0 \\
71 \\
\end{array}$ & $\begin{array}{r}0 \\
33 \\
\end{array}$ \\
\hline Total & & 1.00 & 0 & 0 & 0 & 0 & 1,232 & 4,211 & 9,670 & 4,684 & 8 & 29 & 71 & 33 \\
\hline
\end{tabular}

11540104 Murgab Depression Subsalt Assessment Unit (100\% of undiscovered oil fields and $100 \%$ of undiscovered gas fields allocated to ONSHORE province 1154)

\begin{tabular}{|c|c|c|c|c|c|c|c|c|c|c|c|c|c|c|}
\hline Oil fields & 5 & 1.00 & 39 & 104 & 217 & 113 & 358 & 1,007 & 2,305 & 1,127 & 20 & 59 & 145 & $\begin{array}{r}68 \\
3,607\end{array}$ \\
\hline Gas fields & 30 & & & & & & 37,905 & 130,355 & 279,233 & 140,635 & 913 & 3,237 & 7,572 & 3,607 \\
\hline Total & & 1.00 & 39 & 104 & 217 & 113 & 38,263 & 131,362 & 281,538 & 141,762 & 932 & 3,296 & 7,718 & 3,675 \\
\hline
\end{tabular}


which indicates the absence of active charge from directly underlying Upper Jurassic rocks. The Upper Jurassic evaporite seal is absent in the foredeep, and gas generated in Jurassic and possibly lower Neocomian rocks could have migrated vertically into the Shatlyk sandstones and then laterally updip along the Dauletabad structural nose, losing hydrogen sulfide on the migration path due to reduction of iron. Updip in the structural nose, gas was trapped by the gradation of Shatlyk Bed sandstones into shales. A narrow water-bearing zone is preserved between the gas accumulation and the shale-out line. The importance of this source for gas in filling the northern block of the field is not clear, but it is probably minor.

The Dauletabad field is an excellent example of a giant gas field that is presently in an active stage of its formation (Amursky and others, 1984). The field is in hydrodynamic disequilibrium, which is demonstrated by the eastern GWC, which is tilted about $1,000 \mathrm{~m}$ across the structural monocline, and by the presence of water-bearing zones in the reservoir above the gas pool in the southern part of the field. Such disequilibrium cannot be supported for an extended period of geologic time, and it results from active charge of overpressured gas from underlying Jurassic rocks. The rate of the gas charge should be extremely high on a geologic time scale; this high rate is necessary to fill the huge reservoir and support the hydrodynamic disequilibrium. This, in turn, indicates very high rate of gas generation in Jurassic rocks and its migration to the zone of hydrodynamic connectivity with the Shatlyk reservoir. Much of this gas was probably generated in the North Badkhyz trough, which is filled with thick NeogeneQuaternary clastic sediments (fig. 2). It is possible that continuous charging of the reservoir during exploitation may be significant even over the production life of the field.

\section{Assessment Units}

Four assessment units (AU) were identified in the Amu-Darya Jurassic-Cretaceous TPS (fig. 1). The Northern and Western Areas AU (11540101) encompasses major structures that are located north and west of the area covered by Upper Jurassic salt. The Karabil-Badkhyz AU (11540102) covers the southern area of the basin, south of the pinch-out of Upper Jurassic salt. Both these units are devoid of the Gaurdak salt seal and, thus, possess vertical hydrodynamic connectivity for hydrocarbons migrating from Jurassic source rocks into younger reservoirs. Therefore, both AU include the entire stratigraphic succession from the Jurassic to the Tertiary. The Murgab Depression Suprasalt AU (11540103) and the Murgab Depression Subsalt AU (11540104) are stratigraphically superposed. Both cover the Murgab depression and adjacent areas and are stratigraphically separated by the salt seal of the Upper Jurassic Gaurdak Formation. The assessment results for all four AU are shown in table 1, and supporting statistical data can be found in U.S. Geological Survey World Energy Assessment Team (2000).

\section{Northern and Western Areas Assessment Unit}

The Northern and Western Areas AU (11540101) includes Jurassic and Cretaceous rocks of most of the Bukhara step on the northeast, central, and northern parts of the Khiva-Zaunguz depression on the north, the Karakum high and Beurdeshik step on the northwest, and the Kopet-Dag foredeep and most western part of the Bakhardok monocline on the west (figs. 1, 2). Structurally, this is the most diverse AU; however, its major characteristics are the absence of the Gaurdak Formation salt seal and the resulting wide distribution of hydrocarbon accumulations throughout the stratigraphic succession from Jurassic through Cretaceous rocks, thus permitting the combination of all these structural units into a single AU. Upper Jurassic black shales of the basinal facies are absent in the AU, and the dominant, and probably sole, source rocks are essentially continental coal-bearing Lower and Middle Jurassic clastics. Reservoir rocks are present at various stratigraphic levels from the Middle Jurassic on the shallow basin margins to the Upper Cretaceous. Most discovered reserves are in Lower Cretaceous-Cenomanian rocks either below the upper Aptian or Turonian shale seals. Substantial reserves are also present in Upper Jurassic shallow-shelf carbonates below the shale seal of the uppermost Jurassic Karabil Formation. Reserves in Lower to Middle Jurassic and post-Cenomanian rocks are small. Virtually all reserves are in structural traps.

The undiscovered potential of this areally large AU is relatively limited. All of the large structural traps that are present through all levels of the stratigraphic succession have been explored. The principal remaining potential is in stratigraphic traps that have received little exploration effort throughout the Amu-Darya basin. Most of the stratigraphic traps are expected to be found on the Bakhardok and Beurdeshik steps where Upper Jurassic reservoir carbonates, including Tithonian dolomites that have been proven productive in a few fields, are truncated by the pre-Cretaceous unconformity and sealed by basal Cretaceous shales on slopes of the Karakum high (fig. 2) (Melikhov and others, 1992). Potential stratigraphic traps in these areas also may be related to small (20-30 m high) shelf bioherms, several of which have been detected in CallovianOxfordian and Barremian rocks. Stratigraphic traps in clastic rocks are expected mostly in the Aptian-Albian section, in which sandstone beds pinch out updip on the structural steps (Tashliev and others, 1987; Melikhov and others, 1988).

On the Bukhara and northwestern part of the Chardzhou steps (fig. 2), stratigraphic and combination structural and stratigraphic traps may be found in zones where Lower-Middle Jurassic rocks pinch out on slopes of structural uplifts (Ubaykhodzhaev and others, 1984). In these potential, but unexplored prospects, Lower-Middle Jurassic rocks are at depths of about $2 \mathrm{~km}$, and they possess satisfactory reservoir properties.

Troughout the Northern and Western Areas AU, the Lower-Middle Jurassic sequence is inadequately explored. Most of the wells have penetrated only the upper BajocianBathonian part of the sequence, resulting in about 15 small commercial and noncommercial discoveries. Underlying 
Jurassic rocks remain essentially unexplored. Structural prospects in Lower-Middle Jurassic rocks may include anticlinal traps that were formed in pre-Tertiary time and are buried below undeformed Tertiary and Cretaceous rocks. Formation of the traps could have been related to Triassic and Early Jurassic rifting events. Seismic data of significantly better quality are needed to detect and map such prospects. Some of the anticlines that were formed in Cretaceous time may be expressed in Upper Jurassic and Lower Cretaceous strata and may also be potential exploration objectives. Sandstone bodies related to river-valley fills can be expected in basal strata of the sequence, which were deposited over dissected Triassic erosional relief. This type of trap contains giant oil reserves in Lower Jurassic rocks of the Talin field in West Siberia where Jurassic stratigraphy is similar to that of the Amu-Darya basin (Karagodin and Izarova, 1993). A characteristic of Lower-Middle Jurassic rocks that may substantially decrease their hydrocarbon potential is the poor quality of both reservoir and seal rocks (Maksimov and others, 1986). Because reservoir properties deteriorate at a high rate with depth, the main potential is related to areas where Lower-Middle Jurassic rocks are at depths of less than $3 \mathrm{~km}$.

The potential of the Kopet-Dag foredeep is poorly understood because great drilling depths and inadequate quality of seismic data hinder structural and stratigraphic studies. No discoveries have been made in the largest part of the foredeep, which lies in Turkmenistan, but two gas fields, including the giant Khangiran field (fig. 2), have been found in frontal folds of the Kopet-Dag foldbelt in Iran. The main petroleum potential is believed to be in Upper Jurassic carbonates and Neocomian clastics and carbonates that are productive in the Khangiran field. Two types of potential structural traps are present (Melikhov and others, 1987). The first type includes frontal folds that were formed in Tertiary time; some of the folds are overthrust by the Kopet-Dag Range. The deep structure of these folds is poorly imaged in seismic records, and this may be the reason for several dry holes. The second type of potential structural traps is represented by anticlinal structures that were mapped in the Upper Jurassic-Neocomian strata but are not expressed in younger Cretaceous and Tertiary rocks. Several of these structures, with amplitudes as high as $300 \mathrm{~m}$, have been detected by seismic surveys in the eastern area of the foredeep. Depths to Upper Jurassic rocks in these prospects are approximately 4.5 to $5 \mathrm{~km}$ (Melikhov and others, 1987). Stratigraphic data are insufficient to evaluate potential for stratigraphic traps, but considering the great depth, their potential is probably low.

Almost all undiscovered hydrocarbon resources of the Northern and Western Areas AU are gas with low concentrations of hydrogen sulfide. The content of condensate will be generally low. Small oil pools may be present in the shallow parts of the AU.

\section{Karabil-Badkhyz Assessment Unit}

The Karabil-Badkhyz assessment unit (11540102) includes the Badkhyz-Maimana uplift, Kushka fold zone, narrow Kalaimor trough between the two, and western slope of the North Afghan high and Andhoy uplift in Afghanistan (figs. 1, 2).

The Badkhyz-Maimana uplift occupies the largest area of the AU. It consists of the Badkhyz uplift on the west, the Karabil structural step in the central part, and the prominent Maimana uplift on the east, most of the latter being located in Afghanistan. Only two gas fields, the Dauletabad and Karabil fields, have been discovered in the Turkmenistan part of the $\mathrm{AU}$, and a small, apparently noncommercial oil field has been found in Afghanistan. The Badkhyz-Maimana uplift is characterized by a paucity of anticlinal structures; the only important anticlinal trap detected todate is the Karabil structure, which contains three gas pools in Neocomian, Aptian, and Paleocene rocks with combined reserves of more than 1.5 TCF. Petroconsultants (1996) showed several discoveries on the Maimana uplift in Afghanistan (fig. 1), but none of these discoveries are commercial.

The principal potential of the Badkhyz-Maimana uplift is related to stratigraphic traps. Lower, Middle, and Upper Jurassic, and lower Neocomian rocks, including the Shatlyk Bed, thin southward across the northern slope of the uplift to zero at its higher southern part, where Barremian carbonates locally directly overlie deformed Triassic basement rocks (Smirnov and others, 1980). On the highest part of the Maimana uplift, wells penetrated the basement at depths of less than $1 \mathrm{~km}$ (Bratash and others, 1970). Pinch-out zones of various stratigraphic units, especially Upper Jurassic carbonates and sandstones of the Shatlyk Bed and its stratigraphic equivalents may contain many stratigraphic traps. A part of these traps may be a combination of pinch-outs with structural noses, a number of which are known (Kravchenko and others, 1982), and possibly with hydrodynamic features similar to that in the Dauletabad field. Local reservoir-quality sandstones are present in the Valanginian and lowermost Hauterivian sections (below the Shatlyk Bed). A number of these sandstones have been tested in the Dauletabad field, and some of them produced commercial flows of gas (Melikhov and others, 1990). Prospects of this type probably will be present along the entire northern margin of the Badkhyz-Maimana uplift. The important criterion for exploration of all the stratigraphic traps is the presence of an upper seal. Where there is no effective seal, the reservoir rocks contain water (as, for example, Upper Jurassic carbonates in the Dauletabad field).

The petroleum potential of the Kushka fold zone and shallow Kalaimor depression is limited. Two relatively small gas fields have been discovered in Turkmenistan and one possibly commercial gas field in Afghanistan; a number of shows have also been detected in wells. Middle Jurassic and Lower to Upper Cretaceous rocks are productive in the discovered fields. The fields are in structural traps, the formation of which is related to Neogene orogeny. The folds are readily mappable on the surface, and probably all significant mapped prospects 
have been drilled and tested in this relatively small area. Only the Lower-Middle Jurassic sequence is less substantially drilled, and it may contain some undiscovered potential (Maksimov and others, 1984). Few data are available on this part of the Amu-Darya basin, and it is not known whether the quality of seismic data is adequate to image the deep structure of the folds.

The Andhoy uplift and western slope of the North Afghan high contain all the major discovered fields of Afghanistan, most of which yield gas. At least one significant oil field, the Angot field (fig. 2), is present. Major reserves are in Upper Jurassic carbonates and Lower Cretaceous, largely Hauterivian, clastics. Testing of several structural prospects gave negative results (Bratash and others, 1970). Most wells were drilled before the early 1980s. Little exploration has been conducted since that time, owing largely to the start of the war in Afghanistan, and exploration essentially ceased in the 1990s. Available data are scarce, but it is likely that many structural prospects remain undrilled. In addition, negative results of exploration of many structural prospects may be questioned because of the poor quality of the seismic mapping and testing technology being used.

\section{Murgab Depression Suprasalt Assessment Unit}

The Murgab Depression Suprasalt AU (11540103) covers the Murgab depression and adjacent structural units (or their parts) where the Gaurdak Formation salt is present and separates the subsalt and suprasalt rock complexes (figs. 1,2). The salt is not deformed over most of the $\mathrm{AU}$, and hydrodynamic connectivity between the two complexes is largely absent, except possibly locally along the largest faults and near salt domes of the Repetek-Kelif zone (fig. 2). The absence of hydrodynamic connectivity is emphasized by the fact that few fields productive from Upper Jurassic carbonates in the AU also contain pools in Lower Cretaceous rocks, and all these fields are in marginal zones of the AU. The Murgab Depression Suprasalt AU contains only about a dozen gas accumulations, but among them are some of the largest fields of the AmuDarya basin, such as the Shatlyk field (fig. 2) with more than $30 \mathrm{TCF}$ of gas reserves. Virtually all the reserves are concentrated in sandstones of the Hauterivian Shatlyk Bed. In a number of wells, gas was tested in local carbonate and clastic reservoirs between the top of the Gaurdak Formation salt and the bottom of the Shatlyk Bed, but no significant shows were detected above the Shatlyk Bed in spite of the presence of rocks with reservoir lithologies. The absence of shows in rocks above the Shatlyk Bed indicates the absence of indigenous source rocks and supports the model of long-distance lateral migration of gas from Jurassic sources outside the Gaurdak salt area along the regional Shatlyk reservoir.

All discovered gas accumulations of the AU are in structural traps. However, a number of drilled large anticlinal structures similar to those containing the large and giant gas fields are water bearing. Apparently, the water-bearing structures are positioned outside the routes of lateral migration of gas and have not been charged. Gas in the Murgab Depression Suprasalt AU is devoid of hydrogen sulfide and occurs at moderate depths. The gas pools are characterized by high yields and normal reservoir pressures. Therefore, prospects in this $\mathrm{AU}$ are economically attractive. However, obvious structural plays within the AU have been thoroughly explored, and only small, subtle structures may remain to be found. The potential for stratigraphic traps is not high because of lateral continuity of Shatlyk sandstones over a large area. The best potential for discoveries in stratigraphic and combination stratigraphic and structural traps is probably in the zone across which Shatlyk sandstones pass into evaporitic facies (fig. 13) (Pashaev and others, 1993). Some stratigraphic traps are likely to be present in pre-Shatlyk Lower Cretaceous rocks, but most of them probably were charged with gas only in the vicinity of fields that contain structural gas pools in the Shatlyk reservoir. Other stratigraphic traps in pre-Shatlyk Cretaceous reservoirs were likely bypassed by gas migrating through the Shatlyk sandstones. Stratigraphic traps in younger rocks of the Murgab Depression Suprasalt AU are devoid of petroleum potential, as demonstrated by the complete absence of gas accumulations in structural traps in these rocks.

Detailed data are not available on the structure and state of exploration of the Repetek-Kelif zone. Only two gas fields have been found there, with production from Shatlyk sandstones in structural traps. On the basis of limited data, it appears that the structure of the fields is unrelated to the salt domes that are located along a large regional fault with vertical displacement as much as $1.5 \mathrm{~km}$ in the western part of the zone. This fault may provide an avenue for vertical migration of hydrocarbons from subsalt source rocks into suprasalt reservoirs. Whether salt-dome-assisted traps are present, and may be potential targets for drilling, is not clear because no information on exploration of such prospects is available.

\section{Murgab Depression Subsalt Assessment Unit}

The Murgab Depression Subsalt AU (11540104) includes Jurassic rocks that underlie the Gaurdak Formation in the area where this formation contains salt. The AU encompasses the Murgab depression together with the eastern and southeastern parts of structures adjacent to the northwest-Malay-Bagadzha uplift, most of the Chardzhou and a small southeastern part of the Bukhara steps, the Beshkent depression and the Obruchev trough of northwestern Afghanistan (fig. 2). The unit has been extensively explored on the Chardzhou step, Malay-Bagadzha uplift, and in the Beshkent depression, but there has been little exploration in other areas. The AU contains a substantial part of discovered reserves of the Amu-Darya basin and most of its assessed undiscovered resources.

The majority of the fields discovered in the Murgab Depression Subsalt AU are on the Chardzhou step. The fields are dominantly in Oxfordian carbonate reservoirs in structural, paleogeomorphic (reef), and combinationstructural-paleogeomorphic traps. The gas contains moderate to high concentrations of hydrogen sulfide. The amount of condensate varies widely. Small oil pools 
and oil legs in gas pools are locally present. In spite of a substantial amount of drilling, the petroleum potential of the Chardzhou step and Beshkent depression is not exhausted. The resolution of existing seismic data is rather poor; the principal difficulty in defining prospects is distinguishing between reflectors from the top of carbonates and those from the top of overlying anhydrites, which commonly contain carbonate beds. One of the largest fields of the AU, the Kokdumalak field (fig. 2), was discovered in a well-explored area of the Chardzhou step in 1985, about 30 years after the inception of exploratory drilling. Reef and combination traps contain the bulk of undiscovered resources, much of which is expected to be in the substantially less explored Beshkent depression, where the top of the carbonates is at depths of about $3.5 \mathrm{~km}$.

Three gas fields in Upper Jurassic carbonates have been discovered on the Malay-Bagadzha uplift. These fields are located basinward from the upper Oxfordian barrier reef (fig. 6), and the principal reservoir of the Chardzhou step is absent. The fields are in structural traps, producing from lower Oxfordian carbonates that were deposited at moderate water depths before formation of the deep-water basin. Reservoir properties of these carbonates are much poorer than those of the upper Oxfordian reefs and back-reef facies. Further deterioration of reservoir properties may take place toward the central area of the basin (Alekhin and others, 1982). More structural traps, albeit of smaller size, can probably be found, but the potential of this structural unit is low. The northern part of the Malay-Bagadzha uplift is probably crossed by the upper Oxfordian barrier reef that extends from the Chardzhou step, but no discoveries in the reef facies have yet been reported.

Fields in Upper Jurassic rocks of the southern parts of the Khiva-Zaunguz depression and Beurdeshik step (fig. 2) are in the marginal area of the Gaurdak salt basin. The data are inadequate, but it is likely that the reservoirs are in back-reef carbonate sequences. The shelf edge, which is probably associated with the barrier reef, has not been delineated, but its potential for discoveries in combination traps may be high. The presence of isolated carbonate buildups basinward from the shelf edge has not been proved, although their existence is inferred mainly on the basis of sedimentological models (Abdyllaev and others, 1991). If present, such isolated buildups, which commonly have both higher contents of condensate and large reserves per unit area (2 BBOE in Kokdumalak field with area of only $26 \mathrm{~km}^{2}$ ), may be attractive exploration objectives.

The Murgab depression, including its extension into Afghanistan, is the least explored part of the Murgab Depression Subsalt AU, and it holds the highest undiscovered resource potential. The depression encompasses the facies zones of the Late Jurassic deep-water basin, its completely unexplored southern shelf, and an intervening reef trend. The top of Upper Jurassic carbonate rocks is at depths of about 4 to more than $5 \mathrm{~km}$. By 1998, only 21 wells deeper than $4 \mathrm{~km} \mathrm{had}$ been drilled in the entire Murgab depression (Aleksandrova, 1998). Many more wells were not completed by drilling or not tested due to technical problems, primarily because of abnormally high reservoir pressures. In carbonate beds inside the Gaurdak Formation, reservoir pressures approach geostatic pressure. For example, of five wells that were drilled on the South Yolotan prospect (north of the Dauletabad field in fig. 2), only one was completed and tested (Paitykov and others, 1996).

The location of the Late Jurassic shelf edge has not been mapped because of the lack of wells and inadequate quality of seismic data. Back-reef facies are present on the BadkhyzMaimana uplift and are characterized by relatively good reservoir properties, but they do not have a top seal and tested water in a number of wells in the Dauletabad field (Melikhov and others, 1990). North of this uplift, carbonate rocks were penetrated by several wells in the Shatlyk, Yashlar, and other fields (fig. 2). It is believed that the discovery well in the Yashlar field produced high flows of gas from reef carbonates, but the drilling and testing data remain proprietary. Seismic records contain reflections that are interpreted as indications of the presence of reefs in and to the east of the Yashlar field area (O'Connor and Sonnengerd, 1991) and also in the area between Shatlyk and Dauletabad fields (Allanov and others, 1985). High-quality seismic data in the Yashlar area were acquired in recent years by the Bridas Co. (Argentina). Though the data are proprietary, it is known that the presence of reef bodies has been confirmed, therefore indicating that the entire area between Yashlar and Shatlyk fields on the north and the boundary of the Murgab depression on the south likely possesses high potential for discovery of hydrocarbon (dominantly gas) fields in reef and back-reef carbonate reservoirs. From west to east, this area extends from the westernmost Kopet-Dag foredeep to the western and northwestern slopes of the North Afghan high. Both structural and paleogeomorphic traps and their combinations are expected to be present. The zone is assessed to contain the largest portion of undiscovered hydrocarbon resources of the Amu-Darya basin (table 1). The gas will be mostly sour, with moderate to high concentrations of hydrogen sulfide. The condensate contents probably will be lower than in fields of the Chardzhou step because Upper Jurassic marine source rocks north of the shelf are buried deeper into the gas-generation window.

The petroleum potential of Upper Jurassic rocks of the Murgab depression north of the Late Jurassic shelf is much lower. Upper and probably middle Oxfordian sections are composed of deep-water facies largely devoid of reservoir rocks. Carbonate reservoirs may be present in lower Oxfordian and upper Callovian units, but neither their thickness nor quality are comparable with upper Oxfordian reefs and backreef facies (Nevmirich and others, 1996).

Lower to Middle Jurassic clastic rocks may have limited petroleum potential only in the extreme marginal areas of the Murgab Depression Subsalt AU. In deeper parts of the AU, these rocks lose their reservoir quality because of compaction and diagenetic alterations (Amanov, 1991). 


\section{References Cited}

Abdullaev, G.S., 1999, Detailing of stratigraphy of Upper Jurassic carbonate complex of western Uzbekistan-Basis for increasing effectiveness of oil-gas exploration: Petroleum Geology, v. 33, no. 3, p. 297-304.

Abdyllaev, E.Kh., Ashirov, T., and Paytykov, C.M., 1991, Sedimentological model of Upper Jurassic carbonate formation of eastern Turkmenistan: Sovetskaya Geologiya, no. 12 , p. 48-52.

Akramkhodzhaev, A.M., Abduazizov, A.A., and Ramazanov, S.R., 1981, Formation of oil and gas fields in Mesozoic and Cenozoic rocks of Uzbekistan on the basis of data on stable carbon isotopes in oils, bitumens, and organic matter in source rocks, in Sidorenko, A.V. and Yeremenko, N.A., eds., Organic geochemistry of oils, gases, and organic matter in the Precambrian [Organicheskaya geokhimiya neftei, gazov i organicheskogo veshchestva dokembriya]: Moscow, Nauka, p. 159-163.

Akramkhodzhaev, A.M., and Egamberdyev, M.E., 1985, Rocks of the Upper Jurassic Khodzhaipak FormationProbable Central Asian analogs of the Bazhenov Formation rocks: Geologiya Nefti i Gaza, no. 2, p. 19-24.

Alekhin, S.I., 1984, Hydrodynamic peculiarities of gas fields of eastern Turkmenistan: Geologiya Nefti i Gaza, no. 8, p. 9-14.

Alekhin, S.I., Melnik, N.M., and Khalylov, M., 1982, Prognosis of the stratigraphic range of productivity in Jurassic rocks of Eastern Turkmenistan: Geologiya Nefti i Gaza, no. 3, p. 7-13.

Aleksandrova, S.R., 1998, State of study of Upper Jurassic rocks of southeastern Turkmenistan by deep drilling: Geologiya, Geofizika i Razrabotka Neftyanykh Mestorozhdeniy, no. 5, p. 28-29.

Alekseev, V.P., Babaev, G.A., Safonov, B.K., Troitsky, A.V., and Yeremenko, N.V., 1990, Stratification and correlation of the Jurassic clastic sequence of the Chardzhou step on well log data: Uzbekskiy Geologicheskiy Zhurnal, no. 4, p. 34-39.

Allanov, A., Khudaykuliev, Kh., Abdyllaev, E., and Kabulov, Kh., 1985, Prognosis of petroleum productivity of the Tedzhen zone of uplifts: Geologiya Nefti i Gaza, no. 4, p. 25-31.

Amanniyazov, K.N., 1989, Paleogeography and useful minerals of Upper Jurassic rocks in the western areas of Central Asia [Paleogeografiya i poleznye iskopaemye verkhney yury zapadnykh rayonov Sredney Azii]: Ashkhabad, Turkmenistan, Ylym, 128 p.
Amanniyazov, K.N., and Nevmirich, L.E., 1985, Upper Jurassic reef complexes of eastern Turkmenistan and their petroleum potential [Rifogennye kompleksy verkhney yury Vostochnogo Turkmenistana i perspektivy ikh neftegazonosnosti]: Ashkhabad, Turkmenistan, Ylym, 223 p.

Amanov, S.A., 1991, Effect of postsedimentary processes on reservoir properties of Lower-Middle Jurassic and Hauterivian rocks of the Murgab petroleum region: Izvestiya Akademii Nauk Turkmenskoy SSR, Seriya Fiziko-Tekhnicheskikh, Khimicheskikh i Geologicheskikh Nauk, no. 6, p. 65-68.

Amursky, G.I., Zhabrev, I.P., Solovyev, N.N., and Khusnutdinov, Z.B., 1984, Formation of the Dauletabad-Donmez gas field-Tectonodynamic model of the geologic basis for production: Sovetskaya Geologiya, no. 3, p. 11-21.

Atakhanov, K., 1988, Hydrogen sulfide in gases of JurassicNeocomian rocks of the Kopet-Dag petroleum province, in Kalinko, M.K., and Pankina, R.G., eds., Geochemical criteria for formation of hydrocarbon accumulations and prognosis of petroleum potential [Geokhimicheskiye kriterii formirovaniya skopleniy uglevodorodov i prognoza neftegazonosnosti]: Moscow, VNIGNI, p. 74-82.

Aynazarov, K.K., 1985, Relationship of the structural patterns of Paleogene and Lower Cretaceous rocks in the BadkhyzKarabil region of Turkmenistan: Geologiya Nefti i Gaza, no. 11 , p. $36-39$.

Babaev, A.G., 1993, Oil and gas pools in Jurassic rocks of the Bukhara-Khiva petroleum region: Otechestvennaya Geologiya, no. 2, p. 3-12.

Bakirov, A.A., ed., 1979, Petroleum provinces and regions of the USSR [Neftegazonosnye provintsii i oblasti SSSR]: Moscow, Nedra, 456 p.

Bekker, Ya.A., 1996, Tectonics of the Afghan-Tajik depression: Geotectonics, v. 30, no. 2, p. 64-70.

Beznosov, N.V., Gurari, F.G., Ilyin, V.D., Mesezhnikov, M.S., and Lipatova, V.V., eds., 1987, Reference book on stratigraphy of petroleum provinces of the USSR [Spravochnik po stratigrafii neftegazonosnykh provintsiy SSSR]: Moscow, Nedra, 336 p.

Bratash, V.I., Egupov, S.V., Pechnikov, V.V., and Shelomentsev, A.I., 1970, Geology and petroleum potential of northern Afghanistan, Proceedings of VNIGNI, v. 80 [Geologiya i neftegazonosnost severa Afganistana, Trudy VNIGNI, vyp. 80]: Moscow, Nedra, 288 p.

Brookfield, M.E., and Hashmat, A., 2001, The geology and petroleum potential of the North Afghan platform and adjacent areas (northern Afghanistan, with parts of southern Turkmenistan, Uzbekistan, and Tajikistan): Earth Science Reviews, v. 55, no. 1, p. 41-71. 
Clarke, J.W., and Kleshchev, K.A., 1992, Dauletabad-Donmez field-Commonwealth of Independent States (former USSR), Amu-Darya basin, Turkmenistan/Uzbekistan, in Beaumont, E.A., and Foster, N.H., compilers, Treatise of petroleum geology, Atlas of oil and gas fields, Stratigraphic traps III: American Association of Petroleum Geologists Special Publication, p. 285-300.

Dikenshteyn, G.H., Maksimov, S.P., and Semenovich, V.V., eds., 1983, Petroleum provinces of the USSR [Neftegazonosnye provintsii SSSR]: Moscow, Nedra, 272 p.

Environmental Systems Research Institute, Inc., 1992, ArcWorld 1:3 M digital database: Environmental Systems Research Institute, Inc. (ESRI), available from ESRI, Redlands, CA, scale: 1:3,000,000.

Fortunatova, N.K., 1985, Genetic types and sedimentological models of carbonate deposits: Sovetskaya Geologiya, no. 1, p. 32-45.

Gabrielyants, G.A., Dikenshteyn, G.H., Kapustin, I.N., Kiryukhin, L.G., and Razmyshlyaev, A.A., 1991, Regional geology of petroleum provinces of the USSR [Regionalnaya geologiya neftegazonosnykh provintsiy SSSR]: Moscow, Nedra, 284 p.

Gavrilcheva, L.G., and Pashaev, M.S., 1993, Geologic framework of Upper Jurassic rocks and extension of seismic reflectors in the Amu-Darya basin: Geologiya Nefti i Gaza, no. 11, p. 15-20.

Gavrilov, E.Ya., Goncharov, V.S., and Teplinsky, G.I., 1985, Origin of gas of the Dauletabad-Donmez gas condensate field: Geologiya Nefti i Gaza, no. 9, p. 35-39.

Golovanova, S.I., 1995, Genetic model of the phase zonality of liquid fluids of the Dauletabad-Donmez field: Geologiya Nefti i Gaza, no. 12, p. 21-27.

Goryunov, E.Yu., and Ilyin, V.D., 1994, Methodology of assessment of petroleum productivity of the barrier reef system in the Dengizkul area of the Amu-Darya basin (Uzbekistan): Geologiya Nefti i Gaza, no. 11, p. 13-20.

Heafford, A.P., and Lichtman, G.S., 1993, Uzbek licensing round brings geology, potential into focus: Oil and Gas Journal, August 9, p. 51-56.

Ibragimov, A.G., and Ivanov, E.V., 1984, Genesis of abnormally high formation pressure in Upper Jurassic carbonate rocks of the northern Amu-Darya basin: Geologiya Nefti i Gaza, no. 1, p. 15-19.

Ilyin, V.D., and Fortunatova, N.K., 1988, Methods of prediction and exploration for hydrocarbon-productive reef complexes [Metody prognozirovaniya i poiskov neftegazonosnykh rifovykh kompleksov]: Moscow, Nedra, 2001 p.
Karagodin, Yu.N., and Izarova, L.P., 1993, Morphology of Lower Jurassic productive beds of the Talinskoe deposit, West Siberia: Russian Geology and Geophysics, v. 34, no. 5, p. 30-35.

Khaimov, R.N., Novokshenov, A.M., Khodzhaev, R.A., Zelenin, N.A., Svyatozarsky, E.A., and Savenkova, E.V., 1983, Formation and exploration for tar accumulations in western Uzbekistan: Geologiya Nefti i Gaza, no. 11, p. 38-41.

Khain, V.E., Sokolov, B.A., Kleshchev, K.A., and Shein, V.S., 1991, Tectonic and geodynamic setting of oil and gas basins of the Soviet Union: American Association of Petroleum Geologists Bulletin, v. 75, no. 2, p. 313-325.

Khudaykuliev, Kh., 1986, Main characteristics of the Upper Jurassic evaporite formation and its role in prognosis of buried reefs in the Amu-Darya basin, in Yanshin, A.L., and Merzlyakov, G.A., eds., New data on geology of salt-bearing basins of the Soviet Union [Novye dannye po geologii solenosnykh basseynov Sovetskogo Coyuza]: Moscow, Nauka, p. 101-115.

Khudaykuliev, Kh., Tsepelev, N.S., and Baykhanov, A.A., 1989, New data on the geologic framework and gas potential of Jurassic-Lower Cretaceous rocks of the Shorgel monocline: Izvestiya Akademii Nauk Turkmenskoy SSR, Seriya Fiziko-Tekhnicheskikh, Khimicheskikh i Geologicheskikh Nauk, no. 4, p. 64-70.

Kleshchev, K.A., Slavkin, V.S., Babaev, Kh.K., and Taganov, Yu.A., 1991, Geological-geophysical model of Greater Yashlar: Geologiya Nefti i Gaza, no. 2, p. 16-20.

Korsun, V.V., and Kushnirov, V.V., 1986, Relationship between the phase composition of pools and trap types in Upper Jurassic rocks of southwestern Uzbekistan: Geologiya Nefti i Gaza, no. 7, p. 52-57.

Kravchenko, K.N., Koshelev, N.I., Polkanova, I.N., Smirnov, L.N., Davydov, A.N., Khodzhakuliev, Ya.A., and Khusnutdinov, Z.B., 1982, Duzenkyr structure-Potential objective for oil and gas exploration in Cretaceous rocks of the Badkhyz uplift: Geologiya Nefti i Gaza, no. 7, p. 14-19.

Krylov, N.A., 1979, Geologic criteria of identification of petroleum source sequences on epi-Paleozoic plates of the southern USSR, in Vassoevich, N.B., and Timofeev, P.P., eds., Oil-generative sequences and principles of their identification [Neftematerinskiye svity i printsipy ikh diagnostiki]: Moscow, Nauka, p. 143-148.

Kryuchkov, V.E., 1996, Lithologic composition of the Shatlyk Horizon of the Malay-Chartak zone of uplifts as related to gas potential of eastern Turkmenistan: Geologiya Nefti i Gaza, no. 5, p. 4-10. 
Kuleshov, A.V., and Ignatova, V.A., 1990, Present temperature regime of Jurassic and Lower Cretaceous rocks of the Amu-Darya basin as related to their oil and gas productivity, in Kleschev, K.A., and Shein, V.S., eds., Geology and geodynamics of petroleum basins of the USSR [Geologiya i geodinamika neftegazonosnykh basseynov SSSR]: Moscow, VNIGNI, p. 158-165.

Lomako, P.M., and Khudaynazarov, G.B., 1983, Peculiarities of hydrogen sulfide distribution in hydrocarbon gases in subsalt rocks of eastern Turkmenistan: Geologiya Nefti i Gaza, no. 9, p. 42-46.

Loziev, V.P., Ishanov, M.K., Tyutin, M.A., and Pilguy, Yu.N., 1984, Anomalous deformations of the sedimentary cover in the Soviet part of the Afghan-Tajik basin and their petroleum potential, in Muratov, M.V., Yanshin, A.L., and Garetsky, R.G., eds., Tectonics of the young platforms [Tektonika molodykh platform]: Moscow, Nauka, p. 115-120.

Lyberis, N., and Manby, G., 1999, Oblique to orthogonal convergence across the Turan block in the post-Miocene: American Association of Petroleum Geologists Bulletin, v. 83 , no. 7, p. 1135-1160.

Maksimov, S.P., ed., 1992, Sedimentary cover of Central Asia and south Kazakhstan [Osadochnyi chekhol Sredney Azii i yuzhnogo Kazakhstana]: Moscow, Nedra, 148 p.

Maksimov, S.P., Ilyin, V.D., Kleschev, K.A., Mokcyakova, A.M., Shein, V.S., Mirzakhanov, V.K., Karryev, A.A., and Khodzhakuliev, Ya.A., 1984, Exploration potential of Turkmenistan: Geologiya Nefti i Gaza, no. 1, p. 1-9.

Maksimov, S.P., Kleshchev, K.A., and Shein, V.S., eds., 1986, Geology and geodynamics of petroleum regions of the southern USSR [Geologiya i geodinamika neftegazonosnykh territoriy yuga SSSR]: Moscow, Nedra, 232 p.

Maksimov, S.P., Pankina, R.G., and Smakhtina, A.M., 1987, Conditions of formation of hydrocarbon accumulations in Mesozoic rocks of the Amu-Darya petroleum province: Geologiya Nefti i Gaza, no. 5, p. 20-27.

Mavyev, N.C., 1986, Catagenesis of petroleum-bearing Mesozoic and upper Paleozoic formations of the southwestern Turan plate [Katagenez neftegazonosnykh mezozoyskikh i verkhnepaleozoyskikh formatsiy yugo-zapada Turanskoy plity]: Ashkhabad, Turkmenistan, Ylym, 218 p.

Melikhov, V.N., Sibirev, V.S., Ashirmamedov, M.A., Ataev, A.A., Peshkov, O.N., and Rozhkov, E.L., 1987, Geologic basis and ways of realization of petroleum potential of the Bakhardok slope and Kopet-Dag foredeep, Information Review, Series Petroleum Geology and Geophysics \{Obzornaya Informatsiya, Seriya Neftegazovaya Geologiya i Geofizika], no. 14 (12): Moscow, VNIIOENG, 52 p.
Melikhov, V.N., Khusnutdinov, Z.B., Sibirev, V.S., and Rozhkov, E.L., 1988, Exploration for complexly sealed traps and oil and gas accumulations in the platform part of the Turkmenistan, Information Review, Series Geology and Exploration for Gas and Gas Condensate Fields, [Obzornaya Informatsiya, Seriya Geologiya i Razvedka Gazovykh i Gazokondensatnykh Mestorozhdeniy], no. 4: Moscow, VNIIEgasprom, $40 \mathrm{p}$.

Melikhov, V.N., Sibirev, V.S., Khusnutdinov, Z.V., Klychev, E.R., and Mamedov, B.N., 1990, Exploration for complexly sealed traps and gas pools in the Dauletabad-Donmez field [Poiski i razvedka sloznoekranirovannykh lovushek i zalezhey gaza na Dauletobad-Donmezskom mestorozhdenii]: Ashkhabad, Tirkmenistan, TurkmenNIINTI, 82 p.

Melikhov, V.N., Sibirev, V.S., Ashirmamedov. M.A., Peshkov, O.N., Ataev, A.A., Redzhepov, A., Klychev, E.R., and Geldynazarov, A., 1992, West part of the Bakhardok slope - New petroleum region of Turkmenistan: Geologiya Nefti i Gaza, no. 11, p. 15-19.

Moussavi-Harami, R., and Brenner, R.L., 1992, Geohistory analysis and petroleum reservoir characteristics of Lower Cretaceous (Neocomian) sandstones, eastern Kopet-Dag basin, northeastern Iran: American Association of Petroleum Geologists Bulletin, v. 76, no. 8, p. 1200-1208.

Nedirov, B.R., 1992, Lithology and reservoir properties of oiland gas-productive Lower Cretaceous rocks on the southeast slope of the Turkmen high [Litologiya i kollektorskie svoystva neftegazonosnykh nizhnemelovykh otlozheniy yugo-vostochnogo sklona Turkmenskoy anteklizy]: Ashgabat, Turkmenistan, Ylym, $132 \mathrm{p}$.

Nevmirich, L.E., Alekhin, S.N., Batyrov, S.S., and Kireeva, L.N., 1996, Lithofacies and geochemical characteristics of carbonate rocks of basinal facies in eastern Turkmenistan: Izvestiya Akademii Nauk Turkmenistana, Seriya FizikoMatematicheskikh, Tekhnicheskikh, Khimicheskikh i Geologicheskikh Nauk, no. 5, p. 63-71.

O'Connor, R.B., and Sonnenberg, S., 1991, Amu-Darya liquids potential indicated: Oil and Gas Journal, v. 89, no. 23, June 3, 1991, p. 104-109.

Orazov, O., Tsepelev, N.S., Prilutsky, V.S., and Baranova, L.V., 1985, Physical-lithological characteristics of the gasproductive horizon in fields of the Tedzhen group of structures: Izvestiya Akademii Nauk Turkmenskoy SSR, Seriya Fiziko-Tekhnicheskikh, Khimicheskikh i Geologicheskikh Nauk, no. 1, p. 108-111.

Otto, S.C., 1997, Mesozoic-Cenozoic history of deformation and petroleum systems in sedimentary basins of Central Asia: Implications of collisions on the Eurasian margin: Petroleum Geoscience, v. 3, no. 4, p. 327-341. 
Ovodov, N.E., and Pechernikov, V.V., 1987, Formation of gas fields in basins of the same genetic type but of different age, in Trofimuk, A.A., Nesterov, I.I., and Zhabrev, I.P., eds., Regularities in distribution of hydrocarbon gases and associated components [Zakonomernosti razmeshcheniya uglevodorodnykh gazov i soputstvuyushchikh im komponentov]: Moscow, Nauka, p. 56-61.

Paitykov, C.M., Kireeva, L.N., and Ilamanov, T., 1996, Petroleum potential of Upper Jurassic rocks of the South Yolotan structure: Izvestiya Akademii Nauk Turkmenskoy SSR, Seriya Fiziko-Tekhnicheskikh, Khimicheskikh i Geologicheskikh Nauk, no. 4, p. 50-57.

Pankina, R.G., Mekhtieva, V.L., Bakun, N.I., and Gurieva, S.M., 1986, Isotopic composition of forms of sulfur in the Dauletabad-Donmez gas field as an indication of genesis of hydrogen sulfide: Geologiya Nefti i Gaza, no. 12, p. 51-56.

Pashaev, M.S., Gavrilcheva, L.G., and Redzepov, K.A., 1993, Composition and facies zonality of Lower Cretaceous salt-Formation of non-anticlinal traps in southeastern Turkmenistan: Geologiya Nefti i Gaza, no. 5, p. 15-18.

Petroconsultants, 1996, Petroleum Exploration and Production Database: Petroconsultants, Inc., P.O. Box 740619, 6600 Sands Point Drive, Houston TX 77274-0619, U.S.A. or Petroconsultants, Inc., P.O. Box 152, 24 Chemin de la Mairie, 1258 Perly, Geneva, Switzerland.

Polyakova, I.D., 1977, Regularities in accumulation of organic matter in ancient sedimentary deposits, in Kontorovich, A.E., and Uspensky, V.A., eds., Dispersed organic matter in sedimentary rocks and methods of its study [Rasseyannoye organicheskoye veshchestvo gornykh porod i metody yego izucheniya]: Novosibirsk, Russia, Institut Geologii i Geofiziki, Trudy, v. 334, Nauka, p. 42-55.

Semashev, R.G., 1983, Hydrogeological conditions of gas accumulation in the Murgab depression: Geologiya Nefti i Gaza, no. 10, p. 43-49.

Semenovich, V.V., Maksimov, S.P., Pankina, R.G., Mekhtieva, V.L., and Gurieva, S.M., 1983, Genesis of hydrogen sulfide of the Dauletabad-Donmez field: Geologiya Nefti i Gaza, no. 6 , p. 32-37.

Smirnov, L.N., Kravchenko, K.N., Koshelev, N.I., Barash, B.I., Butuzov, P.N., and Davydov, A.N., 1980, Direction of geologic exploration for oil and gas on the BadkhyzMaimana uplift, in Koshelev, N.I., and Smirnov, L.N., eds., Geologic framework and criteria for prediction of petroleum potential of Central Asia [Geologicheskoye stroeniye i kriterii prognoza neftegazonosnosti Sredney Azii]: Trudy VNIGNI, v. 220, p. 5-38.
Sokolova, I.M., Abryutina, N.I., Makarov, V.V., Kuldzhaev, B.A., Rusinova, G.V., and Petrov, Al.A., 1993, Biomarkers in gas condensates of eastern Turkmenistan: Geokhimiya, no. 1, p. 123-130.

Starobinets, I.S., 1974, Geological and geochemical characteristics of gas condensates [Geologo-geokhimicheskiye osobennosti gazokondensatov]: Leningrad, Nedra, $152 \mathrm{p}$.

Tashliev, M.S., and Znamenskaya, G.A., 1991, Oil and gas reservoirs in Cretaceous rocks of the southern Turan plate: Izvestiya Akademii Nauk Turkmenskoy SSR, Seriya FizikoTekhnicheskikh, Khimicheskikh i Geologicheskikh Nauk, no. 5 , p. $79-85$.

Tashliev, M.S., Yuferov, R.F., Tovbina, S.Z., Davydov, A.N., Kosoy, D.E., and Kuryleva, A.M., 1985, Lithostratigraphy of hydrocarbon-productive rocks of Turkmenistan [Litostratigrafiya neftegazonosnykh otlozheniy Turkmenistana]: Ashkhabad, Turkmenistan, Ylym, $230 \mathrm{p}$.

Tashliev, M.S., Allaberdyev, S.B., and Tolbina, S.Z., 1987, Non-anticlinal oil and gas traps in Cretaceous rocks of Turkmenistan: Geologiya Nefti i Gaza, no. 4, p. 26-31.

Ubaykhodzhaev, T.I., Khaimov, R.N., Korsun, V.V., Novokshenov, A.M., and Zelenin, N.A., 1984, Exploration for oil and gas fields in the southeastern part of the Bukhara step: Geologiya Nefti i Gaza, no. 9, p. 12-15.

Ulmishek, G.F., 2001, Petroleum geology and resources of the Middle Caspian basin, former Soviet Union: U.S. Geological Survey Bulletin 2201-A, 38 p., available online at http://pubs.usgs.gov/bul/b2201-a.

U.S. Geological Survey World Energy Assessment Team, 2000, U.S. Geological Survey World Petroleum Assessment 2000-Description and results: U.S. Geological Survey Digital Data Series 60, 4 CD-ROMs.

Vakhabov, A., 1986, Geologic framework of the lower part of Upper Jurassic evaporites in western Uzbekistan: Uzbekskiy Geologicheskiy Zhurnal, no. 2, p. 29-33.

Viktorova, N.S., Telkova, M.S., and Fedotova, A.I., 1988, Hydrocarbon composition in organic matter of Hauterivian rocks of the Dauletabad-Donmez gas condensate field, in Kalinko, M.K., and Pankina, R.G., eds., Geochemical criteria for formation of hydrocarbon accumulations and prognosis of petroleum potential [Geokhimicheskiye kriterii formirovaniya skopleniy uglevodorodov i prognoza neftegazonosnosti]: Moscow, VNIGNI, p. 133-142.

Yermolkin, V.I., 1986, Zonality of oil and gas accumulation on platforms [Zonalnost neftegazonakopleniya na platformennykh territoriyakh]: Moscow, Nedra, 185 p. 
Zonenshayn, L.P., Kuzmin, M.I., and Natapov, L.M., 1990, Tectonics of lithospheric plates of the USSR [Tektonika litosfernykh plit territorii SSSR], volumes I and II: Moscow, Nedra, 328 and $336 \mathrm{p}$.
Zykin, M.Ya., Kuzmuk, L.G., and Chichmareva, A.V., 1992, Development of low-porosity reservoir rocks in the Shatlyk Bed of the Dauletabad-Donmez field: Geologiya Nefti i Gaza, no. 6, p. 23-25.

Manuscript approved for publication July 16, 2004

Published in the Central Region, Denver, Colorado

Edited by Richard W. Scott, Jr.

Page layout, photocomposition and section 508 compliance by Amber Swallow

Webmaster-Tracy A. Pinto

Graphics by the author 